\title{
Examining the Value of Money in America over the Long Term (1792-2009)
}

\author{
Adam Abdullah ${ }^{1}$ \\ ${ }^{1}$ Faculty of Business Management and Accountancy, Universiti Sultan Zainal Abidin, Kuala Terengganu, \\ Malaysia \\ Correspondence: Adam Abdullah, Faculty of Business Management and Accountancy, University Sultan Zainal \\ Abidin, Gong Badak Campus, 21300 Kuala Terengganu, Terengganu, Malaysia. Tel: 609-668-8275. E-mail: \\ aabdullah@unisza.edu.my
}

Received: August 15, 2013

Accepted: September 2, $2013 \quad$ Online Published: September 26, 2013

doi:10.5539/ijef.v5n10p58

URL: http://dx.doi.org/10.5539/ijef.v5n10p58

\begin{abstract}
This paper aims to examine the significant loss of value of money over the long term in America between 1792-2009. One U.S. dollar in 1792 is now worth only two cents by 2009. By critically examining the value and purchasing power of money in America, this paper compares empirical evidence and statistics through long term analysis of gold, silver and commodity price indices, as to which medium of exchange provides for the best store of value. This paper finds that monetary policy should not target stable prices, by managing the quantity or purchasing power of money, but instead adopt a monetary theory of value involving a stable currency, free of any monetary management or manipulation, permitting a stable purchasing power and thus stable prices.
\end{abstract}

Keywords: gold price, silver price, commodity prices, value of money, purchasing power of money

\section{Introduction}

This paper aims to analyze the store of value function of money by investigating historical empirical evidence and statistics, to analyze the value of money (VM) over the long term over 218 years in America between 1792-2009. The purchasing power of money (PPM) is the inverse of prices and measures the erosion of the value of money due to inflation (Rothbard, 1983), it would not tell us what is that cause of inflation, and we must distinguish between the rate of exchange between currency and a fixed amount of bullion being the VM, and the ratio of exchange between currency and commodities being the PPM (Ricardo, 2004). In other words, the VM is distinct from what money can buy at a particular point in time. By investigating the VM, the PPM and wholesale commodity prices (CP) in America, a monetary theory of value accurately interprets their inter-relationships and causality. Changes in the general level of commodity prices, reveals the relative value of money (Warren, 1935). Price movements are statistically defined in the form of a price index and the reciprocal is the index for the PPM (Fisher, 1911). The purchasing power of gold (PPG) or the purchasing power of silver (PPS) involves how many commodities can be bought with a certain amount of gold or silver. This statistically requires indices for the price of gold (PG) or silver (PS) divided by an index for CP, in order to analyze changes in the PPM, and the affect on prices.

An investigation into the VM and the impact on prices over the long term involves both comparability and continuity and in terms of the PPM (such as gold and silver). In considering CP, we are evaluating whether commodity prices take into account the VM in terms of bullion equivalents (Beveridge, 1965), which are calculated by multiplying CP by an index of the VM as reflected in the value of its gold content (GC) or silver content (SC), in order to obtain real prices (CPgc or CPsc), where GC or SC (the bullion value of currency) are the inverse of indices for the PG and the PS (the currency value of bullion). The dollar adjusted by prices, or the purchasing power of the dollar (PPD), may be contrasted with the dollar adjusted by gold (USDg) or silver (USDs) being equal to the intrinsic value of currency (GC, SC). Whatever the decline in the VM, the American gold and silver dollar coins and the paper dollar, have remained over the long term as a medium of exchange, a unit of account and as a standard of deferred payment, however, what altered was not the unit of account, but the store of value, which is measured by changes in the VM and the PPM.

Jastram $(1977,1981)$ presented an empirical study of money in England and the America between 1560-1979. He concluded that gold and silver had become very manipulated, and did not regard gold as money (Jastram, 
1977), although admitted that the PPG was constant over the long term, acting as a hedge against deflation instead of inflation (Jastram, 1977). He dismissed silver and fiat money as being subjected to significant manipulation and devaluation over the long term (Jastram, 1981) but stipulated that money should still be managed (Jastram, 1977). Jastram could not have foreseen the highly inflationary period following the publication of his works and although Jill Leyland (2009) updated his data up to 2007, her analysis on the modern gold market provided no meaningful insight as to the behaviour of the PG, its manipulation through interest rates and the effect on CP. In this regard, our findings support Abdullah (April, 1913) who solved the Gibson Paradox and explained the relationship between the real price of gold (PPG), real prices and real interest rates under a fractional reserve gold standard and under the fractional reserve fiat standard. The analysis of data in England between 1259-2009 firmly rejected Jastram's interpretation (Abdullah, March 2013) and when we consider the findings of this paper, it is now clearly evident that the same principle applies across whatever geography, background or chronology: when a monetary theory of value prevails, by maintaining a high value of circulating specie, the affect on the purchasing power of money, is such that the general price level remains low and stable over the long term.

This paper is organized into four main sections. In the first section we have provided an introduction concerning the analysis of the VM and the PPM in America over the long term. The second section details the compilation of indices for the PG, PS and CP from 1792-2009. The third section our findings and analysis of American data, and in the fourth section we provide some concluding remarks.

\section{Compilation of Gold, Silver and Commodity Price Indices}

The average annual prices of the PG and the PS in prevailing fineness and troy ounces are preferably compiled (1) by the market price, or (2) by the official price, in that order. The market price represents the PG or PS arrived at freely between individuals, whereas the official buying price represents the published price at which the U.S. mint stood ready to purchase bullion. However, analysis on the market and official price are influenced by the political and economic dominance of England over America as its colony until 1776, and England's continued economic influence given trans-Atlantic trade and London as the centre of the gold and silver market. Hence, one cannot evaluate America data without considering any English influence. With the establishment of the Bank of England (1694), the market PG and PS varied between the bank's buying price and the bank's selling price (the mint price). By the time of the gold standard (1816), the Bank controlled the market PG (Frankel, 1953), and a market PS had already developed for the Spanish dollar ("Pieces of Eight"), which was adopted by the Americans.

The official U.S. price of gold or silver has always been determined by an Act of Congress in defining the value of the dollar in terms of gold or silver under a bimetallic standard. The New York Private Market Price of gold or silver reflects the private market price of gold or silver available in the U.S. for the average American citizen, and captures bank note depreciation during specie suspensions. Periods when specie payments were suspended were (1) 1814-1817, (2) 1837-1843, (3) 1857, (4) 1862-1878 (and of course, after the U.S. went off the gold standard altogether in 1933). During the first suspension, Gallatin (1831) recorded the rise in price of bank notes in terms of a percentage monthly depreciation, in New York between 1814 and 1817, when the redemption of coins for notes was suspended, and the banks had expanded the supply of notes. By averaging the annual rate of depreciation (D) we may obtain the currency value of gold or silver (V), expressed in dollars (or multiplied by 100 for cents),

$$
\text { Currency value of gold or silver: } V=\frac{100}{(100-D)}
$$

Hence, in order to calculate the market price of gold or silver (P), expressed in dollars per fine troy ounce, we multiply the official price (OP) by $\mathrm{V}$, or $\mathrm{P}=\mathrm{OP} \mathrm{x} \mathrm{V}$. Moreover, we may now quantify the amount of depreciation in terms of the gold or silver value of the currency (VC), expressed in cents (2),

$$
\text { Gold or silver value of currency: } V C=\frac{O P}{P} \times 100
$$

This is, of course, the same as if we had calculated $\mathrm{V}$ in terms of the gold or silver value of currency, expressed in cents, $\mathrm{VC}=100-\mathrm{D}$. Therefore, through either of the following formulae we may obtain the gold or silver value of currency, expressed in dollars $(3,4)$,

$$
\text { Gold or silver value of currency: } V C=\frac{O P}{P}
$$




$$
\text { Gold or silver value of currency: } V C=\frac{(100-D)}{100}
$$

By way of example, the average annual currency bank note depreciation in New York in 1815 was $10.375 \%$, the official price was USD19.3939/oz, and our adjusted private market price of gold was USD21.64/oz (Note 1). By adopting the above formulae, during the periods of specie suspension, our New York private market price of gold obtained, conforms exactly to those prices quoted in Warren (1935) and in Mitchell (1908), and also reflects the bank note depreciation in Gallatin (1831). The same formulae were then also applied to adjust the official price of silver by the equivalent level of bank note depreciation, to obtain the equivalent New York private market price of silver. Again, by way of illustration, the official price of silver in 1815 was USD1.2929/oz, and our adjusted private market price of silver was USD1.4426/oz (Note 2).

In New York, beyond the foreign exchange market that operated during the gold standard, for the average American citizen there was no material gold market and the private market price was equal to the official price. Similarly, there was no open market price of silver as such in the United States under the bimetallic standard which existed from $2^{\text {nd }}$ April 1792 until silver was de-monetized on 12 February 1873, whereupon a market price of silver did develop in New York from 1874 (Clarke, 1974). Accordingly, the New York Private Market Price largely reflected the official price that was available for the average American citizen for gold, and for silver up until 1874. As an alternative, we have also considered a New York Market Price of gold or silver, given the dominance of the London bullion market, and in particular, the important trans-Atlantic trade and foreign exchange market. For our New York Market Price of gold (per STO of 0.917 fine) from 1792-1967, and for silver (adjusted per FTO) from 1792-1783, the English market price of gold and silver was converted into dollars at the prevailing exchange rate, unadjusted for bank note depreciation (since the value of the USD would have been reflected in the market exchange rate); for silver from 1874 we have taken actual New York quotations; and for both gold and silver from 1968 prices were based on LBMA dollar quotations. From 1792-1873, there were no New York silver price quotations and no meaningful silver market under the bimetallic standard, until after silver was de-monetized in 1873 (Clarke, 1974) (Leavens, 1939). Any transactions in New York between buyers and sellers and their brokers were not as organized as the London market. The "official" market price set by Handy and Harman originally reflected the London price but was later based on actual prices in New York, usually at $1 / 4 \%$ below the market given its principle function as a basis for settlement between mines and smelters (Leavens, 1929) and 1/4\% being the difference between refined and unrefined silver (Clarke, 1974).

The Cowles Commission (Leavens, 1929) and Jastram $(1977,1981,2009)$ chose London market gold and silver prices converted into dollars. Their evidence implied that, whilst these prices reflected market conditions that prevailed in England, they also captured the depreciation of the currency during periods of suspension through the exchange rate. Even though Officer affirmed that "the mint price of gold or silver is the value of domestic money that the mint will coin per physical unit of bullion deposited with it" (2007), he argued that the official price of gold and silver was the market price from 1791-1932, given that there was no meaningful bullion market in New York for the private citizen, and similarly for the domestic mining industry from 1933-1967 (Officer, 2013-a). Ultimately, we are ascertaining the function of money as a store of value, and the effect of changes in the VM on the general price level, the PPG or PPS, so we have retained the New York Market Price for comparison purposes, being the London market price converted into dollars at the prevailing exchange rate. Our New York Market Price of gold or silver is obtained by multiplying the London market price of gold or silver by the prevailing dollar exchange rate, which initially revolved around an (English) Act of 31 July 1789 until an Act of 3 March 1873, stipulated the $£: \$$ exchange rate was fixed at $\$ 4.44$ (at par), with rates quoted at a premium or discount to parity - the nominal parity of $\$ 4.44$ continued thereafter with exchange rates expressed at a discount/premium or an index to parity (Officer, 2007) (Note 3).

Table 1 presents the sources for the compilation of the price of gold in America as defined as the New York Private Market Price of Gold (1792-2009); table 2 presents the underlying English sources for the compilation of the price of gold in America as defined as the New York Market Price of Gold (1792-2009), which are converted into USD at prevailing exchange rates. Furthermore, table 3 presents the sources for the compilation of the price of silver in America as defined as the New York Private Market Price of Silver (1792-2009); table 4 presents the underlying English sources for the compilation of the price of silver in America, as defined as the New York Market Price of Silver (1792-2009) which are converted into USD at prevailing exchange rates. 
Table 1. Compilations of the New York private market price of gold, 1792-2009

\begin{tabular}{cccc}
\hline Source & Period & Frequency & Denomination \\
\hline Warren and Pearson (Note 4) & $1792-1934$ & annual official price (Note 5) & \$/FTO of 24k (Note 6) \\
U.S. Treasury (Note 7) & $1935-1967$ & annual official price (Note 8) & \$/FTO of .995 gold \\
LBMA (Note 9) & $1968-2009$ & annual market price (Note 10) & \$/FTO of .995 gold \\
\hline
\end{tabular}

Table 2. Compilations of the New York market price of gold, 1792-2009

\begin{tabular}{|c|c|c|c|c|}
\hline \multirow{2}{*}{ Source } & \multirow{2}{*}{ Period } & \multirow{2}{*}{ Frequency } & \multicolumn{2}{|c|}{ Denomination } \\
\hline & & & $£$ & $\$$ \\
\hline $\begin{array}{l}\text { Houghton, Castaing's, Lloyd's List } \\
\text { (Note 11) }\end{array}$ & 1693-1789 & annual market price & £/STO .917 gold (Note 12 ) & \$/STO .917 gold \\
\hline $\begin{array}{l}\text { Parliamentary Papers } 1819 \text { (Note } \\
\text { 13) }\end{array}$ & $1790-1818$ & annual market price & £/STO .917 gold & \$/STO .917 gold \\
\hline $\begin{array}{l}\text { Lutyens' Course of the Exchange } \\
\text { (Note 14) }\end{array}$ & $1819-1832$ & $\begin{array}{l}\text { annual market price } \\
\text { (Note. 15) }\end{array}$ & £/STO .917 gold & \$/STO .917 gold \\
\hline $\begin{array}{l}\text { Sharps, Pixley Ltd London (Note } \\
16 \text { ) }\end{array}$ & $1833-1967$ & annual market price & $\begin{array}{l}\text { £/STO } .917 \text { gold to } 1918 \\
\& .995 \text { ex } 1919\end{array}$ & $\begin{array}{l}\text { \$/STO } .917 \text { gold to } \\
1918 \& .995 \text { ex } 1919\end{array}$ \\
\hline LBMA (Note 17) & $1968-2009$ & annual market price & $£ /$ FTO of 995 gold & \$/FTO of 995 gold \\
\hline
\end{tabular}

Source: Abdullah (March 2013).

Table 3. Compilations of the New York private market price of silver, 1792-2009

\begin{tabular}{cccc}
\hline Source & Period & Frequency & Denomination \\
\hline U.S. Treasury (Note 18) & $1792-1873$ & annual official price (Note 19) & \$/FTO \\
Bureau of Mines (USGS) (Note 20) & $1874-1967$ & annual market price (Note 21) & \$/FTO \\
LBMA (Note 22) & $1968-2009$ & annual market price (Note 23) & \$/FTO \\
\hline
\end{tabular}

Table 4. Compilations of the New York market price of silver, 1792-2009

\begin{tabular}{|c|c|c|c|c|}
\hline \multirow{2}{*}{ Source } & \multirow{2}{*}{ Period } & \multirow{2}{*}{ Frequency } & \multicolumn{2}{|c|}{ Denomination } \\
\hline & & & $£$ & $\$$ \\
\hline $\begin{array}{l}\text { Houghton, Castaing's, Lloyd's List } \\
\text { (Note 24) }\end{array}$ & $1693-1810$ & annual market price & $£, s, d$ per STO $(92.5 \%)$ & $\$ /$ FTO \\
\hline Parliamentary Papers 1819 (Note 25) & $1811-1818$ & annual market price & $£, s, d$ per STO & $\$ /$ FTO \\
\hline $\begin{array}{l}\text { Lutyens' Course of the Exchange } \\
\text { (Note 26) }\end{array}$ & $1819-1832$ & annual market price & $£, s, d$ per STO & $\$ /$ FTO \\
\hline Sharps, Pixley Ltd London (Note 27) & 1833-1967 & annual market price & $\begin{array}{l}£, s, d / \text { STO to } 1944, \& .999 \\
\text { silver ex } 1945\end{array}$ & $\$ /$ FTO \\
\hline LBMA (Note 28) & 1968-2009 & annual market price & $£$ decimal from 1971 & $\$ /$ FTO \\
\hline
\end{tabular}

Source: Abdullah (March, 2013).

The ability to compile American data is relatively straight-forward, with the advantage of being a young nation, emerging in an era when data analysis was becoming more organized, so that historical material was consistently and accurately recorded: bullion prices were derived from the U.S. Mint or from published market sources, and commodity prices from the Bureau of Labor's wholesale price index, the latter being one of the longest and most comprehensive price indices of it's kind. Table 5 presents the sources for wholesale commodity prices.

Table 5. Compilations of American commodity prices, 1792-2009

\begin{tabular}{cccc}
\hline Source & Period & Time Base or Currency & Price Measure \\
\hline Warren and Pearson (Note 29) & $1792-1933$ & $1910-1914$ & wholesale \\
Bureau of Labor Statistics (Note 30) & $1933-2009$ & 1982 & wholesale \\
\hline
\end{tabular}

As part of our research into the performance of the purchasing power of the dollar (PPD), an analysis of the mechanics of the gold market is required to further examine as to why the PG and the PS have both underperformed especially since 1980 in relation to prices in terms of real gold (PPG), real prices (in terms of gold) and real interest rates.

In evaluating the performance of the various American monetary systems, we have provided an analysis of both the long-term stability and short-term volatility of prices (Mueller, 2010). However, this serves to not only rank the medium of exchange, but also the performance of the prevailing monetary authorities. Nonetheless, we have adopted two measures of comparison for the relevant periods: (1) long term price stability measured by the 
average absolute annual change in $\mathrm{CP}$, and (2) short term volatility, measured by the standard deviation of annual CP changes, derived from the population standard deviation (5),

$$
\sigma=\sqrt{\frac{\sum(x-\bar{x})^{2}}{n}}
$$

We can rank each monetary system by weighing stability and volatility equally. Our bullion and price series involves the compilation of a full population of data and additional statistical analysis involves determining the correlation coefficient for a full population to measure the strength of dependence between the PG and the CP in order to assess the decline in the VM upon CP. However, by determining a full population of real prices in terms of gold $(\mathrm{CPgc})$, we may precisely explain causality between a decrease in the store of value and higher nominal $\mathrm{CP}$ (in terms of dollars).

\section{Discussion and Analysis}

In this section we will detail the American monetary standard, then clarify and present our findings concerning the New York Private Market Price of gold or silver and the New York Market Price. We will also highlight important aspects relating to the VM and the PPM concerning the USD that require analysis involving $19^{\text {th }}$ century bimetallism and the de-monetization of silver; the Federal Reserve and the gold standard; the Great Depression; the modern gold market; and performance analysis of the various American monetary systems.

\subsection{The American Monetary Standard}

The silver dollar was derived from the silver Spanish dollar and under the Coinage, or Mint Act of April 1792, a U.S. dollar was defined as 371.25 grains of pure silver or 416 grains of standard silver (standard silver being defined as 1,485 parts fine silver to 179 parts alloy, or 0.8924 fine). The dollar was defined in terms of both gold of 24.75 grains, so that the official price of gold was USD 19.3939/FTO $(=480 / 24.75)$, and silver of 371.25 grains, so that the official price of silver was set at USD 1.2929/FTO (= 480 troy grains/371.25), fixing a bimetallic gold:silver ratio at 15:1. Gold eagle coins were minted worth ten dollars, weighing 270 grains with 247.5 grains of gold $(247.5 / 270=0.917$ fineness $)$. In June 1834 the gold standard was modified to 23.2 grains altering the gold:silver ratio to $16: 1(371.25 / 23.2)$ : the gold eagle was altered to weigh 258 grains with 232.0 grains of gold $(232 / 258=0.8992$ or 21.58 carats). Under the Coinage Act of January 1837, the proportion of alloy in both gold and silver coins was made equal at 10\% (defined as 1,000 parts by weight, with 900 parts pure metal, and 100 parts alloy): the weight of the silver dollar was reduced to 412.5 grains with 371.25 grains of silver; the gold dollar weighed 25.8 grains with 23.22 grains of gold and the eagle coin (worth ten dollars) weighed 258 grains with 232.2 grains of gold, or 0.9 fine (21.6 carats). Hence, the gold standard was adjusted to 23.22 grains of pure gold fixing the price of gold to USD20.67/oz ( 480 grains per oz/23.22 $=20.67$ ), and altering the gold:silver ratio to $15.99: 1$ (371.25/23.22). Silver was effectively de-monetized in favour of a de facto gold standard following the Coinage Act of 1873 (the 'Crime of 73'), which only recognized gold as the metallic standard and the gold dollar as the unit of value. Under pressure from domestic silver miners and farmers, the Bland-Allison Act of 1878 re-introduced the bimetallic monetary policy of the U.S. with a silver dollar standard of 412.5 grains with 371.25 pure grains, thereby maintaining a silver price of USD 1.2929/FTO with a gold:silver ratio still at 15.99:1, but also introduced a silver purchase programme. It was replaced by the Sherman Silver Purchase Act of 1890, which did not grant the free and unlimited coinage of silver, but did increase government purchases of silver with issues of redeemable (for either gold or silver) Treasury notes, which were redeemed for gold and depleted the nation's gold reserves, and was repealed in 1893 immediately following the 'Panic of 93'. Under the Gold Standard Act of 1900, gold was established as the only standard for redeeming paper money, and the U.S. embraced the gold standard 'de jure'. Authorized under the Gold Reserve Act of $30^{\text {th }}$ January 1934, Roosevelt by Presidential Proclamation on $31^{\text {st }}$ January, then fixed the weight of the dollar to 15.238 grains of standard 0.9 gold containing 13.714 grains of pure gold, or an official price of gold at USD35/FTO (= 480/13.714), thus devaluing the gold dollar by $40.94 \%(23.22-13.714 / 23.22)$ to $59.06 \%$ of its previous value (13.714/23.22). In 1972 the dollar was officially devalued to $\$ 38 / \mathrm{oz}$, and defined as " $\$ 1$ equals one thirty-eighth of a fine troy ounce of gold", thus 480/38 = 12.5316 grains of gold per dollar. In 1973 the dollar was defined as, "\$1 equals 0.828948 Special Drawing Rights or, the equivalent in terms of gold, of forty-two and two-ninths dollars per fine troy ounce of gold", or 480/42.2222= 11.3684 grains per dollar. Ultimately, the official U.S. price of gold or silver has always been determined by an Act of Congress in defining the value of the dollar in terms of gold or silver under a bimetallic standard. The official gold:silver ratio was 15 from 1792-1834, 16 from 1834-1836, 15.99 from 1837-1873, and from 1874 the market gold:silver ratio widened with the de-monetization of silver in 1873 . Table 6 summarizes the value of the dollar. 
Table 6. Gold and silver value of the American dollar, 1792-present

\begin{tabular}{cccccccccc}
\hline Legal & \multicolumn{3}{c}{ Gold Dollar (troy grains) } & \multicolumn{3}{c}{ Silver Dollar (troy grains) } & \multicolumn{2}{c}{ Gold:Silver } \\
Date & Purity & Standard & Fine & Price & Purity & Standard & Fine & Price & Ratio \\
\hline 2 Apr. 1792 & 0.9167 & 27.00 & 24.75 & 19.39 & 0.9167 & 416.00 & 371.25 & 1.29 & 15.00 \\
28 June 1834 & 0.8992 & 25.80 & 23.20 & 20.69 & 0.8924 & 416.00 & 371.25 & 1.29 & 16.00 \\
18 Jan. 1837 & 0.9000 & 25.80 & 23.22 & 20.67 & 0.9000 & 412.50 & 371.25 & 1.29 & 15.99 \\
12 Feb. 1873 & 0.9000 & 25.80 & 23.22 & 20.67 & & & & & \\
28 Feb. 1878 & & & & & 0.9000 & 412.50 & 371.25 & 1.29 & 15.99 \\
14 Mar. 1900 & 0.9000 & 25.80 & 23.22 & 20.67 & & & & & \\
31 Jan. 1934 & 0.9000 & 15.24 & 13.71 & 35.00 & & & & & \\
18 Dec. 1971 & & & 12.63 & 38.00 & & & & & \\
13 Feb. 1973 & & & 11.37 & 42.22 & & & &
\end{tabular}

Source: Officer, 2007, pp. 15-16.

Given the various changes in the value of money that occurred within the American monetary standard, what impact was there upon commodity prices and what can we learn from the PPG, PPS, PPD, and the value of the dollar in terms of gold (USDg)? Before we present our findings, we should clarify the choice of market price relating the PG and the PS. As previously mentioned, a market price of bullion would be preferred over an official mint price, but no such market existed in the U.S., since the bullion market was (and still is today) dominated by London. Do we cater to a price (the New York Market Price of gold or silver), reflecting trans-Atlantic trade and the foreign exchange market, or one available to the average American citizen (the New York Private Market Price of gold or silver) (Note 31)?

The New York Market Price of gold or silver reflects the dominance of the London bullion market, and the important trans-Atlantic trade and foreign exchange market. For this price series, for gold (per English STO of 0.917 fine) from 1792-1967, and for silver (adjusted from the English STO of 0.925 to FTO for a better comparison with the U.S. Mint price per FTO) from 1792-1783, we have taken the English price of bullion at the prevailing dollar exchange rate, unadjusted for bank note depreciation; for silver from 1874 we have taken actual New York quotations; and for both gold and silver from 1968 prices were based on LBMA dollar quotations. The English market price of gold or silver in dollars at prevailing $£: \$$ market exchange rates would have captured the depreciation of the currency, for those periods that the payments of specie were suspended, when the price of the bank note increases in relation to coinage, and can be observed in the American gold or silver value of currency. From 1792-1873, there were no New York silver price quotations and no meaningful silver market under the bimetallic standard, until after silver was de-monetized in 1873 (Clarke, 1974) (Leavens, 1939). Any transactions in New York between buyers and sellers and their brokers were not as organized as the London market. The "official" market price set by Handy \& Harman originally reflected the London price but was later based on actual prices in New York, usually at $1 / 4 \%$ below the market given its principle function as a basis for settlement between mines and smelters (Leavens, 1929) and 1/4\% being the difference between refined and unrefined silver (Clarke, 1974). The Cowles Commission (Leavens, 1929) for silver, and Jastram $(1977,1981,2009)$ for gold and silver, chose London market prices converted into dollars.

The New York Market Price of gold or silver is obtained by multiplying the English market price of gold or silver by the prevailing dollar exchange rate, which initially revolved around an (English) Act of 31 July 1789 until an Act of 3 March 1873, stipulating the $£: \$$ exchange rate was fixed at $\$ 4.44$ (at par), with rates quoted at a premium or discount to parity - the nominal parity of $\$ 4.44$ continued thereafter with exchange rates expressed at a discount/premium or an index to parity (Officer, 2007). The predominant instrument in the American foreign exchange market prior WWI was an order to pay a specific amount of money in cash in the form of the sterling bill of exchange. Drawn on a British party, denominated and payable in pounds, bills were traded by brokers and foreign exchange dealers. The dollar-sterling exchange rate was given by the bill's dollar market-price/pound face-value ratio, and the bill was then shipped to England for payment. Upon presentation, a demand bill was redeemed at its pound face-value immediately by the drawee, whilst a time bill was "accepted" (written on the bill by the drawee, signed and dated) and as an "acceptance" (i.e. a "banker's acceptance"), could be sold ("discounted") in the London discount market - for a 60-day bill it would be presented in 63 days (60 days +3 days grace period) to the drawee for payment (Officer, 2007, p. 61). From 1791-1912 the exchange rate data is derived from actual transactions based on "sight" ("demand") bills of exchange. From 1913 the data is derived from "cable transfers" ("telegraphic transfer") whereby pounds are received the same day that dollar payment is made - the trans-Atlantic cable was laid in 1866 but by 1913 the Federal Reserve's fees for cable transfers were almost the same as demand bills (Note 32). The New York Market Price of bullion relies on the English price of bullion and the foreign exchange market. From 1837 the exchange rate was $£ 1=$ USD 4.866 at par (113/23.22). 
The cost of shipping gold from London to New York was USD0.026 per GBP, so the exchange rate of USD 4.866 was allowed to fluctuate +/- USD 0.026 (figure 1).

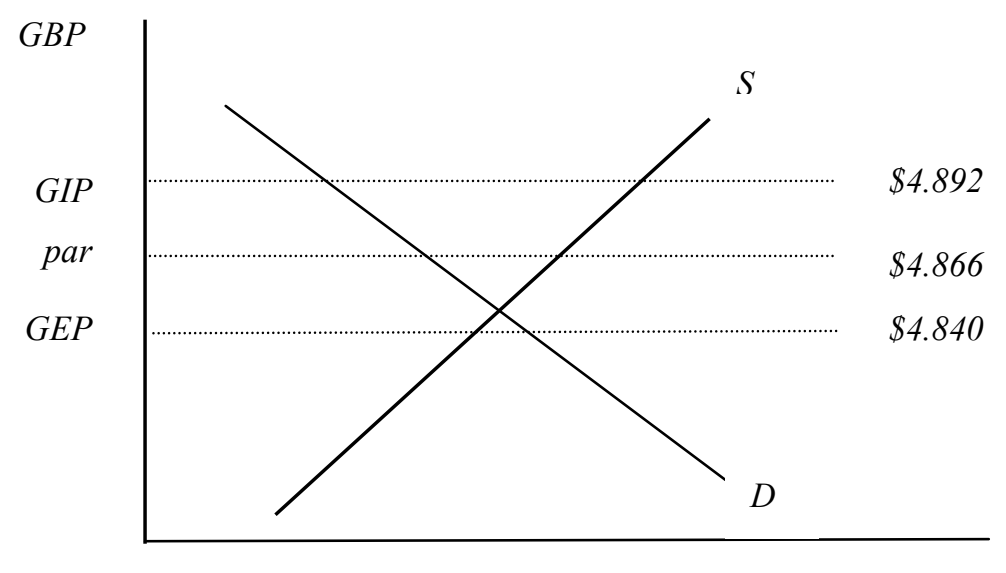

Quantity of Money

Figure 1. Supply and demand of money under the gold standard

Thus USD 4.892 equaled the gold import point (GIP), and USD 4.84 equaled the gold export point (GEP), for the U.K. The cost of remitting gold, or the GEP, is the exchange rate at which it becomes cheaper to convert pounds into gold and remit gold (rather than use the foreign exchange market), before converting the gold into dollars to make dollar payments. Conversely, if the value of the pound increased above the GIP, then it is cheaper to import gold, convert into pounds and then convert the pounds into dollars in the foreign exchange market to make dollar payments. Under the gold standard, central banks controlled gold flows by managing interest rates: for example, when the exchange rate approached the GEP, the Bank would increased the bank rate and a higher interest rate in London would attract funds from New York investors, and the increase demand for pounds would thereby increase the strength of the pound back towards the par exchange rate.

The New York Private Market Price of gold or silver reflects the private market price of gold or silver available in the U.S. for the average American citizen and accurately captures bank note depreciation during specie suspensions. Periods when specie payments were suspended (and America was off any gold or silver standard) were; (1) 1814-1817; (2) 1837-1843; (3) 1857; and (4) 1862-1878. The New York Private Market Price of gold or silver would have been available for every American citizen at the Mint across the entire continent of the United States, and we can explore in more detail the affect of the depreciation of the value in bank notes and measure its impact upon commodity prices. The difference between the New York Private Market Price and New York Market Price of gold or silver is the treatment of the periods that adopt the English gold price (1792-1967) or silver price (1792-1873) at the prevailing exchange rate, with differences in fineness and unadjusted for bank note depreciation during periods of specie suspension, which should be reflected in the prevailing exchange rates.

In figures 2-3, we present the PG, CP, and the PPG and observe the inter-relationships that exist between them. In particular, how CP follows the PG, and that over the long term the PPG is constant. Moreover, whilst the New York Private Market Price for bullion in theory better reflects the available price of gold or silver for the average American citizen, it was in reality no more than an official or mint price, and the New York Market Price of bullion impacted the price level being a genuine market price. That the English price of bullion and the associated foreign exchange market, would have such an effect on American CP, would not be dissimilar to the value of the contemporary USD now affecting global economies. Indeed, the inflation associated with a devalued paper pound during the Restriction Period in the early $19^{\text {th }}$ century, was exported to the United States, notwithstanding the Second Revolutionary War between the U.S. and England in 1812 (which England also lost). 


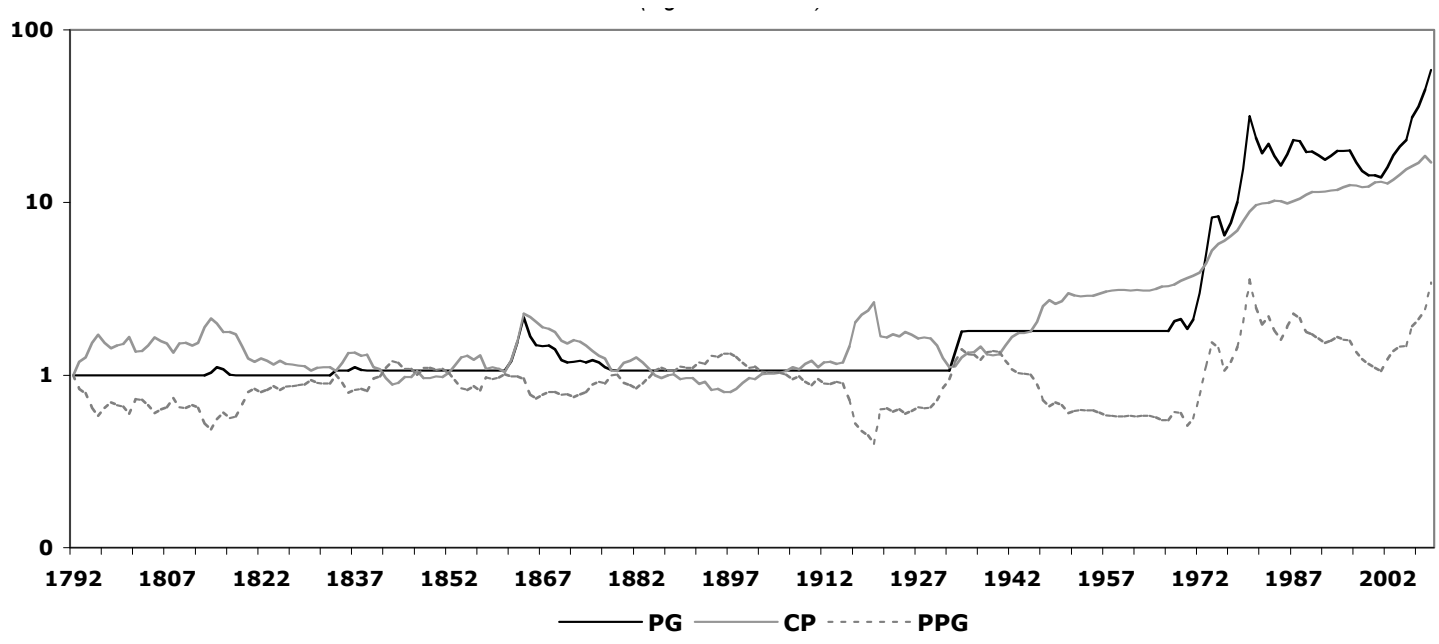

Sources: (PG) - WP, UST, LBMA, (CP) - WP, BL

Figure 2. Indices of the New York private market price of gold (PG), wholesale commodity prices (CP), and the purchasing power of gold (PPG), America, 1792-2009 (1972=1) (logarithmic scale)

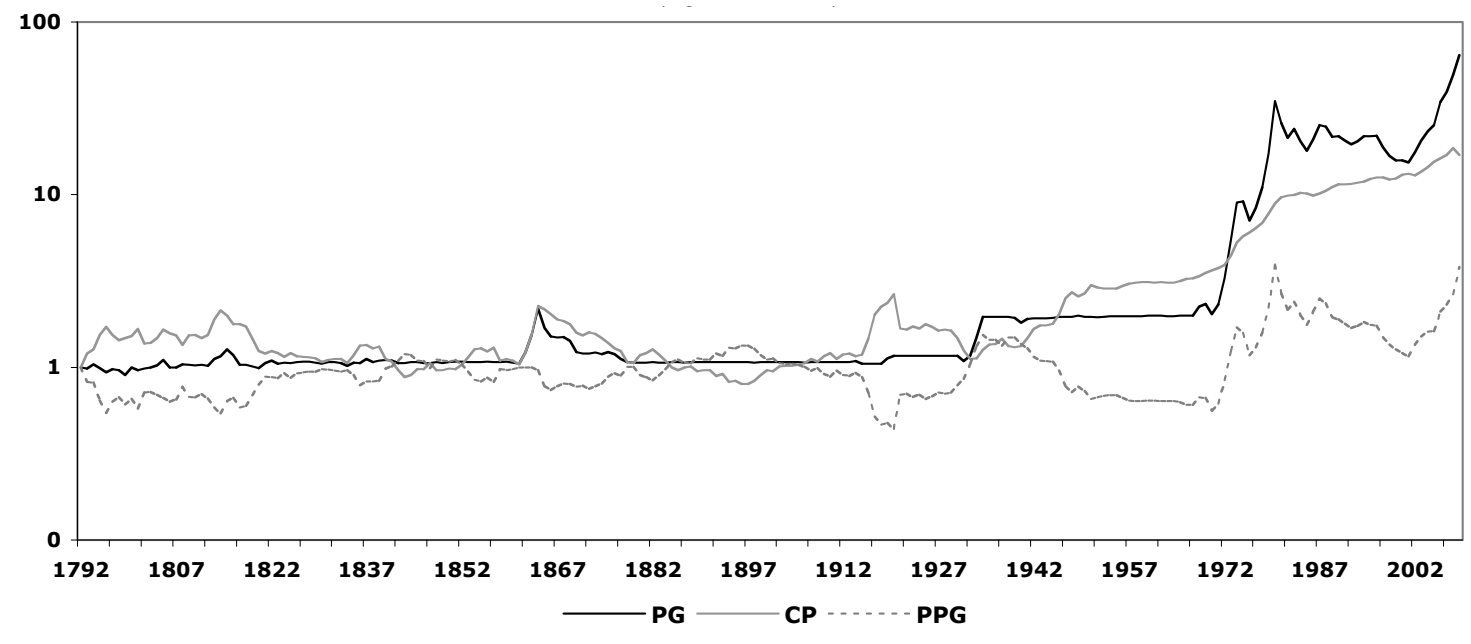

Sources: $(P G)$ - HCL, PP, L, SP, LBMA; (X-rates) - W, O ; (CP) - WP, BL.

Figure 3. Indices of the New York market price of gold (PG), wholesale commodity prices (CP), and the purchasing power of gold (PPG), America, 1792-2009 (1972=1) (logarithmic scale)

The dominance of the London bullion market influenced the PG or PS in America, which is reflected in the movement of commodity prices. Specifically, England was on a de facto gold standard and was on a gold standard de jure from 1816. Bank of England payments were suspended between 1797 and 1821, which increased the price of bullion. We also present figures 4 and 5 regarding the PS, CP and the PPS. The New York Market Price of silver was clearly influenced by the London gold price in relation to the prevailing value of money in New York, and furthermore, America and England were at war in 1812. As with the PPG, the PPS is also constant over the long term. 


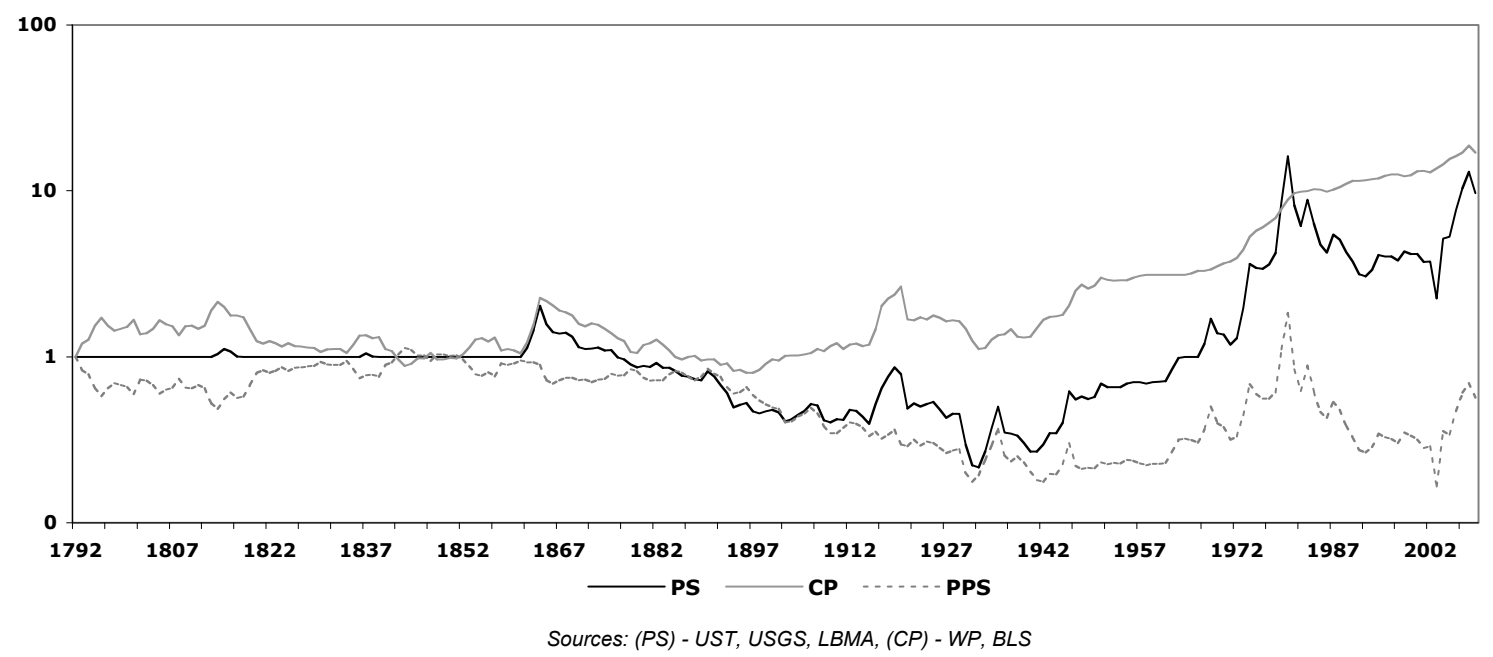

Figure 4. Indices of the New York private market price of silver (PS), wholesale commodity prices (CP), and the purchasing power of silver (PPS), America, 1792-2009 (1972=1) (logarithmic scale)

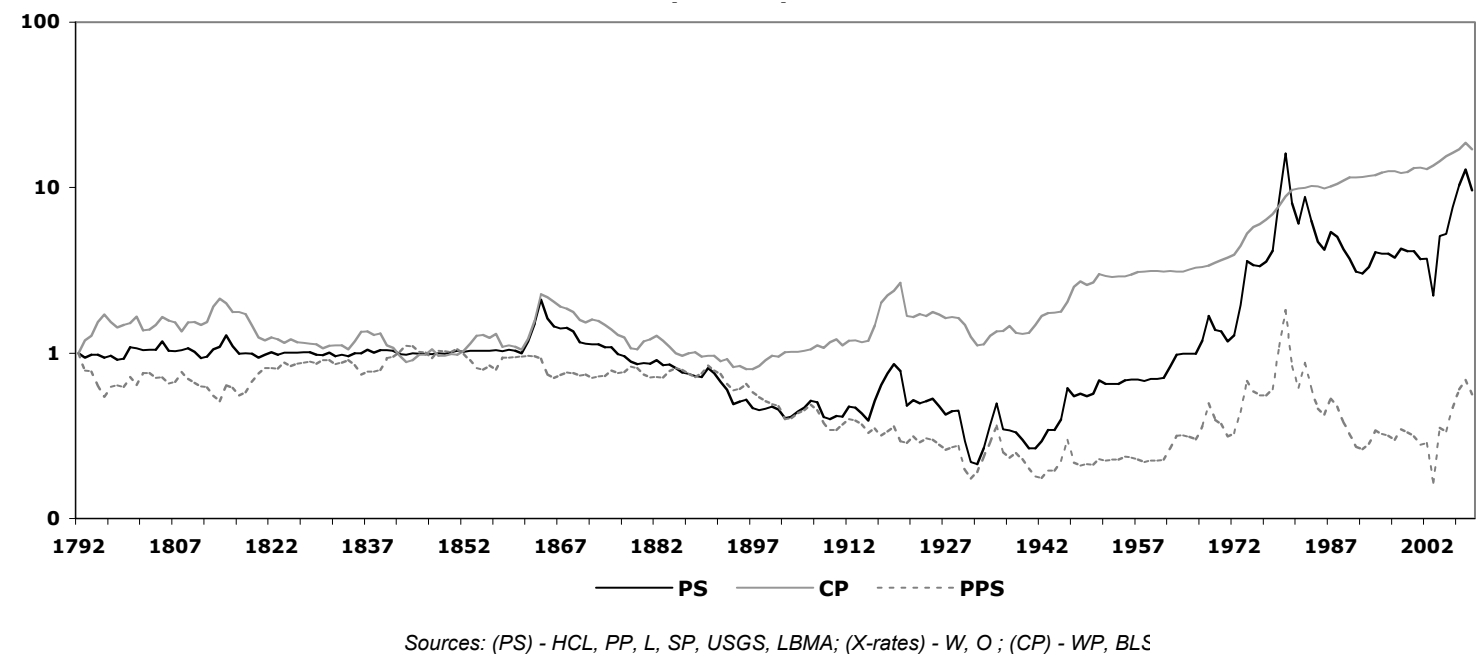

Figure 5. Indices of the New York market price of silver (PS), wholesale commodity prices (CP), and the purchasing power of silver (PPS), America, 1792-2009 (1972=1) (logarithmic scale)

Whilst, depreciation of American paper dollars would not have been reflected in the price of English bullion, it no doubt would have reflected in the foreign exchange market and is captured in the New York Market Price, although the exact amount of depreciation is more obvious in the New York Private Market Price of bullion during the periods of specie suspension in (1) 1814-1817; (2) 1837-1843; (3) 1857; and (4) 1862-1878. The broad sweep reveals a similar pattern between gold and silver, in that whilst the dollar was defined as a weight of precious metal, gold was hedge against deflation until the fiat standard until 1971 when, no longer defined as a precious metal, but backed by the assets of the banks (debt), it became a hedge against inflation. Silver behaved the same way, although the PPS reduced following the decline in the PS due to the de-facto gold standard in combination with the de-monetization of silver in 1873.

\subsection{Bimetallism and the De-Monetization of Silver}

In June 1834 the gold standard was modified to 23.2 grains altering the gold:silver ratio to $16: 1$ (371.25 silver/23.2 gold grains). Under the Coinage Act of January 1837, the proportion of alloy in both gold and silver coins was made equal at $10 \%$, and the weight of the silver dollar was reduced to 412.5 grains with 371.25 grains of silver, and the gold dollar weighed 25.8 grains with 23.22 grains of gold. Hence, the gold 
standard was adjusted to 23.22 grains of pure gold fixing the price of gold to USD20.67/oz ( $=480$ grains per oz/23.22), and altering the gold:silver ratio to $15.99: 1$ (371.25/23.22). Yet, the market ratio in London in 1834 was 15.7:1, which meant that when the U.S. Mint ratio went to $16: 1$ in 1834, the Congress had over-valued gold and did not subsequently reduce the official ratio below the prevailing market ratio, resulting in a de facto gold standard from 1834, which was reinforced with the de-monetization of silver (1873), that saw a slow substitution of gold for silver, which accelerated by 1850 (the Mint also started to issue gold dollars under the Coinage Act of 1849).

Increased global gold production with the first gold rush in California (from 1848), Australia (from 1851), and later with the usage of potassium cyanide for extracting gold from low-grade ore, South Africa (1890) and Klondike (1896) also became significant producers of gold from mines previously thought uneconomic to mine. Between 1850 and 1857 cumulative annual gold production increased by $187.5 \%$, whilst the London gold:silver ratio fell in tandem from 15.6:1 to 15.5:1, so that, with an official U.S. Mint ratio of 15.99:1, large amounts of gold flowed into the U.S. and, by the same process of Gresham's Law, silver flowed out: "the contraction of silver caused a great public inconvenience, since the small coinage of man-in-the-street commerce was largely silver in composition" (Jastram, 1981, p. 66), so that eventually no silver dollars were left in circulation. This is the same Congress that voted to extend the charter in 1832 of the privately owned central bank and Rothschilds dominated (Mullins, 1983, p.50), Second Bank of the United States (1816-1836), but was vetoed by President Jackson due to the Bank's fraud (of money creation) and corruption (of political rivals in Congress).

The advantage of the New York Private Market price is that it allows us to transparently investigate the affect on the value of money during periods when specie payments were suspended: (1) 1814-1817, (2) 1837-1843, (3) 1857, (4) 1862-1878. During the first suspension, Gallatin (1831) recorded the rise in price of bank notes in terms of a percentage monthly depreciation, in New York between 1814 and 1817, when the redemption of coins for notes was suspended, and the banks had expanded the supply of notes. The rates of depreciation differed in other cities such as Baltimore and Philadelphia, thus implying that the supply and demand of notes were not uniform. Nonetheless, when adopting the New York price of bank notes, we may observe in table 7, that their rates of depreciation represent the exact difference between the official price and market price of gold (or silver), whether expressed as the currency value of gold, or in terms of the gold value of currency.

Table 7. Depreciation of bank notes and greenbacks during periods of suspension of payments

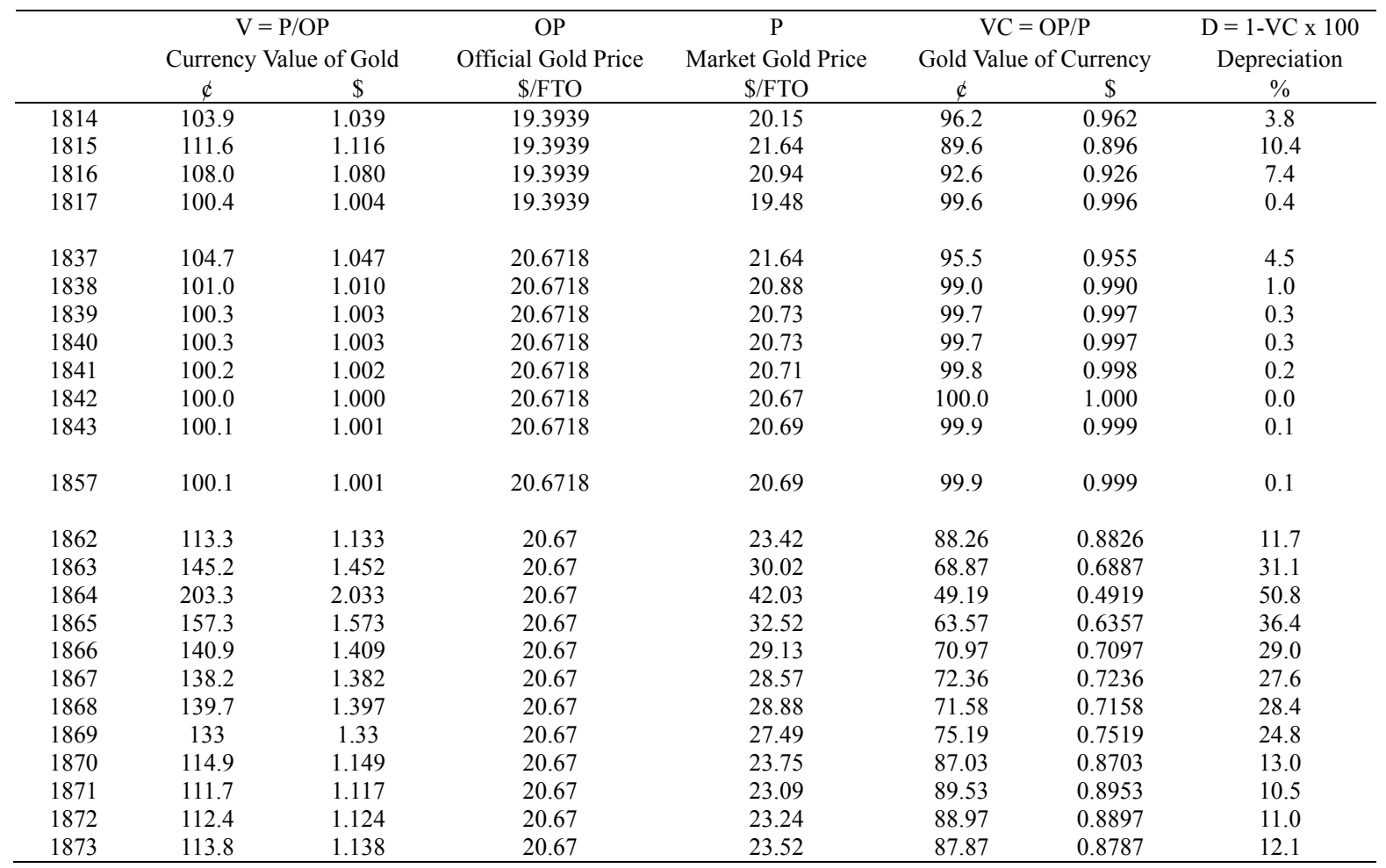




\begin{tabular}{llllllll}
\hline 1874 & 111.2 & 1.112 & 20.67 & 22.99 & 89.93 & 0.8993 & 10.1 \\
1875 & 114.9 & 1.149 & 20.67 & 23.75 & 87.03 & 0.8703 & 13.0 \\
1876 & 111.5 & 1.115 & 20.67 & 23.05 & 89.69 & 0.8969 \\
1877 & 104.8 & 1.048 & 20.67 & 21.66 & 95.42 & 0.9542 \\
1878 & 100.8 & 1.008 & 20.67 & 20.84 & 99.21 & 0.9921 \\
\hline
\end{tabular}

Warren (1935); Mitchell (1908); Gallatin (1831).

During the American Civil War (1861-1865), dollars were issued without precious metal backing from $31^{\text {st }}$ December 1861 and only reinstated in January 1879. Under the Legal-Tender Act of February 1862, Lincoln's 'greenbacks' involved U.S. currency notes being issued by the U.S. Treasury, without incurring debt at interest from a central bank, which would otherwise have issued central bank currency notes. However, the amount of paper notes issued to finance the civil war was nonetheless inflationary (figure 6) - greenbacks depreciated by $36.4 \%$ in 1865 alone, as a result of the excessive supply of money in relation to demand, the effect of which was to increase the price level, and thereby reduce the PPS, since the dollar was defined as a fixed weight of gold or silver under a bi-metallic standard, that drove out both gold as well as silver as a medium of exchange.

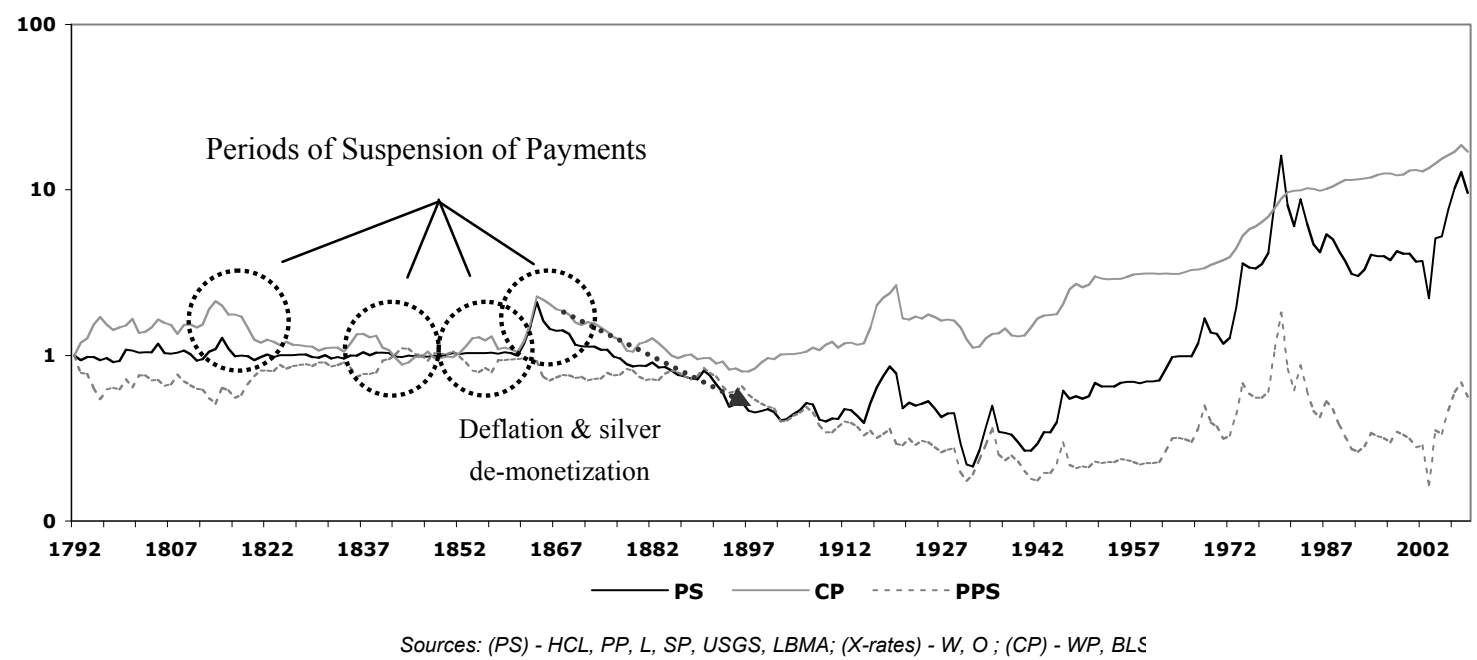

Figure 6. Indices of the New York market price of silver (PS), wholesale commodity prices (CP), and the purchasing power of silver (PPS), America, 1792-2009 (1972=1): Specie suspensions and silver de-monetization

Generally though, as with the PPG, the same stability is found in the PPS until silver was effectively de-monetized in favour of a de facto gold standard following the Coinage Act of 1973 (the Crime of 73), which only recognized gold as the metallic standard, and the gold dollar as the unit of value. Apparently, Rothschilds arranged (Note 33) the end of the free coinage of silver in 1873 because they controlled the gold market and since England was the world's creditor nation, the Bland Allison Act of 1878 also permitted the creditor to dictate that debts were payable in gold alone (Harvey, 1894). The de-monetization of silver resulted in a 23 -year deflationary trend (figure 6), with prices declining by $49 \%$ or $2.1 \%$ p.a. between 1873 and 1896 . By placing the U.S. on a mono-metallic rather than bi-metallic standard, coupled with increased silver supply, the effect was to depress the price of silver, even though the U.S. did not embrace the gold standard 'de jure' until 1900. The PPS still held up for another 17 years until 1890, and thereafter steadily eroded, until Roosevelt purchased all newly-mined silver under the Silver-Purchase Proclamation of December 1933 at a mint equivalent price of 64.65 cents and "nationalized" all private holdings under the Silver Purchase Act of May 1934 at a mint equivalent price of 50.01 cents: the Treasury accumulated 3.2 billion ozs and added about USD2 billion to the stock of money between 1934 and 1961 (Note 34).

\subsection{The Federal Reserve System and the Gold Standard}

Shortly after the Federal Reserve was established in December 1913, World War I began (WWI: 1914-1918), during which time, the gold standard ceased to function, and inflation increased as a result of excessive paper money created by central banks under the fractional reserve banking system. Post-WWI, fluctuating exchange rates occurred as nations adjusted their economies, adopting deflationary policies (causing high unemployment) 
in order to restore pre-war exchange rates. The gold standard was restored in England under the Gold Standard Act of 1925 and Bank notes could be redeemed but only in 400oz bars. Internationally, between 1925 and 1931 , under the restored post-WWI gold standard, or rather under a gold exchange standard, nations held dollars and pounds as reserve assets and were convertible into gold between central banks but not the public. At restored parities the pound was slightly over-valued at USD4.866 and since Britain held balance of payment deficits there was a gold outflow, which eventually led to a suspension of gold payments in September 1931 under the Gold Standard (Amendment) Act of $21^{\text {st }}$ September 1931 (the date signaling the end of the gold standard period), floating the pound on the foreign exchange market and eventually all countries followed.

Ultimately, under executive order 6102 signed in April 1933, President Roosevelt confiscated all privately held gold at the official price of USD20.67; under the Gold Reserve Act of January 1934, Roosevelt then fixed the price of gold at USD35/oz or 15.238 grains of standard 0.9 gold containing 13.714 grains of pure gold (hence $480 / 13.714=$ USD35), thus devaluing the gold dollar by $40.94 \%(23.22-13.714 / 23.22)$, to $59.06 \%$ of its previous value (13.714/23.22), whilst creating nearly USD3 billion in paper profit (Note 35), the economic effect of which was the creation of new fiat money by the same amount. The price of gold remained at USD35 until 1971, upon the collapse of the 1944 Bretton Woods system of fixed exchange rates, where all currencies were pegged (within a $1 \%$ band) to the U.S. dollar, itself convertible into gold at USD35/oz. When the U.S. suspended convertibility, the U.S. dollar was no longer a gold standard currency for central banks, but a became itself the reserve currency, no longer backed by gold, but by debt. Up to 1971 the dollar was defined as a fixed weight of gold and hence the PPG and the PPD moved in tandem, as reflected in figure 7.

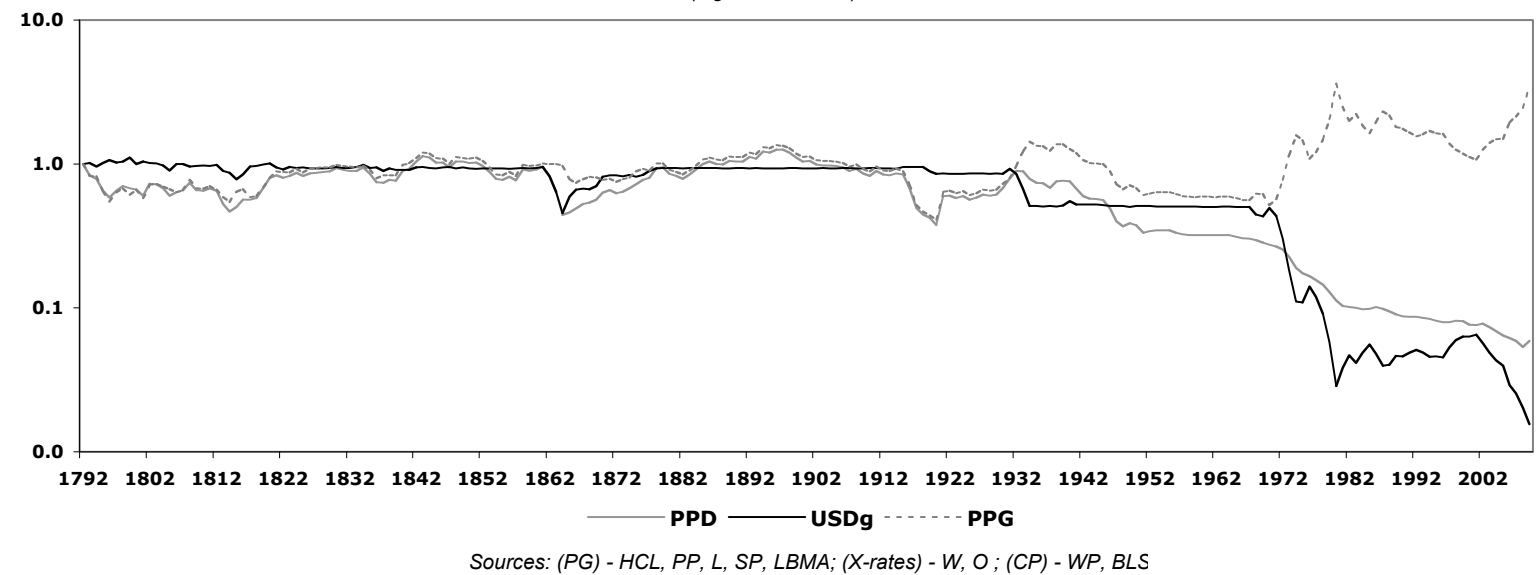

Figure 7. Indices of the value of the dollar in terms of gold (USDg), the purchasing power of gold (PPG), and of the dollar adjusted by wholesale prices (PPD), America, 1792-2009 (1972=1) (logarithmic scale)

Fractional reserve banking originally arose with the advent of goldsmith bankers at the end of the $16^{\text {th }}$ century, and the establishment of the Bank of England in 1694, whom issued an ever-increasing volume of unfunded credit and paper notes in circulation. The same can be said of the U.S. dollar with the three earlier attempts at a U.S. central bank between 1781 and 1836, free-banking from 1837-1862 and national banks from 1863-1913, culminating in the fourth attempt at implementing a private central bank, with the Federal Reserve System established in 1913. On closer analysis, we discover that since the redeemable paper dollar and gold was inter-changeable by virtue of the fact that the dollar was defined in terms of a fixed weight of gold, hence in periods of deflation, the PPM increased and hence the PPD and the PPG increased. Conversely, the PPG and the dollar faired poorly during periods of inflation as prices increased, so the PPG and the PPD decreased. The dollar was heavily influenced by the fact that the England was on a gold standard, and was itself effectively on a de facto gold standard since 1834, reaffirmed from 1873 with the de-monetization of silver, and de jure since 1900. As America left the gold standard (1933) and the gold exchange standard (1971), the decline in the VM and the PPM is very evident post 1971, in terms of value (USDg) and purchasing power (PPD). Prior 1971, gold was the linchpin of the global monetary system, but post 1971 gold was removed and exists as a form of money outside the global monetary system: not surprisingly this affected the relationship of gold and the dollar. Given the supply and demand of dollars, gold generally became a hedge against inflation rather than deflation. $\mathrm{PPD}=1 / \mathrm{CP}$, with prices expressed in dollars. The USDg reflects the gold content (GC) of the dollar, being the index of the 
market value of the dollar expressed in grams of pure gold, where GC $=1 /$ PG. In figure 7 we can observe in that the decline in the VM, of the USD, has reduced the PPM. Monetary collapse is a consequence of rapid and sustained price inflation as a result of an exponential rate of decay in the VM, clearly the paper dollar is discovering its true intrinsic value - zero.

With the inexorable demise of the value and purchasing power of the dollar even well before 1971, American monetary theorists and economists such as Ludwig Von Mises in 1952 called for a return to the classic gold standard (not the gold exchange standard), "Gold must be in the cash holdings of everybody. Everybody must see gold coins changing hands, must be used to having gold coins in his pockets, to receiving gold coins when he cashes his pay-cheque, and to spending gold coins when he buys in a store" (Von Mises, 1981). The rapid devaluation of debt based paper money is inevitable without precious metal backing: on the other hand, a pure $100 \%$ gold standard is impossible with debt at interest (since a debt is always greater than cash received) and money creation from fractional reserve banking. As we have shown, by controlling interest rates, the Bank of England and other central banks, under a fractional reserve gold standard, controlled international flows of gold and silver, that saw the citizens of both England and the United States migrate from bi-metallism although primarily utilizing silver coinage, to a gold standard (1816) involving mono-metallism following the de-monetization of silver (1873), then a non-redeemable gold standard (1931 England, 1933 America), a gold exchange standard involving dollars redeemable in gold only between central banks (1944) and then left with just debt organized into paper money (1971).

\subsection{The Great Depression, 1929-WWII}

In monetary economics, the quantity theory of money stipulates that the money supply has a direct proportional relationship with prices. The quantity theory holds that nominal income is determined by the quantity of money, as reflected in Fisher's equation of exchange MV=PT (Fisher, 1911), where the cumulative quantity (Q) of goods and services reflected in trade $(\mathrm{T})=$ real output $(\mathrm{Y})$, thus $\mathrm{MV}=\mathrm{PY}$, where $\mathrm{M}=$ money supply, $\mathrm{V}=$ velocity of money in circulation, $\mathrm{P}=$ aggregate price level (inflation), and $\mathrm{Y}=$ real output of goods and services (being a function of productivity and labour, i.e. employment). The equation of exchange measures the growth in the monetary sector (MV) being the monetarist counterpart of the Keynesian $\mathrm{C}+\mathrm{I}+\mathrm{G}+\mathrm{Xn}$ (consumption, investment, government expenditure and net exports) $=\mathrm{AE}$ (aggregate expenditure on finished products in one year), and the real economy, being the market value or price level multiplied by the physical output of goods and services (PY), as measured by nominal GDP, whereas real GDP adjusts for price changes to accurately measure changes in output separate from changes in prices. Monetarists hold that $\mathrm{V}$ is generally constant in the short run, rising during the expansion phase of a business cycle and declining during the contraction phase (Friedman, 1963). Since V (being the inverse of the demand for money) is stable, a direct predictable relationship therefore exists between M and nominal GDP, but between 1929-1933, the velocity of money actually declined by one third, as a result of numerous bank failures (Friedman, 1963), so that there was an increase in the demand for currency, being Federal Reserve demand notes, redeemable for gold. Given that the Federal Reserve had already reached its $40 \%$ reserve ratio, there was only enough gold to cover $40 \%$ of notes outstanding. Any withdrawal of gold to meet redemption meant a reduction in bank gold reserves, which would be accompanied by a reduction in credit.

Wholesale commodity prices were flat prior to the Wall Street Crash of 1929, the U.S. was still under the gold standard up to 1933, but commodity prices fell by 30\% between 1929-1933, and yet Rothbard (in 1963) claimed the deflationary depression was "caused by an increase in money supply attendant upon bank credit expansion" in the 1920s, which "led to the ensuing depression-adjustment period" (Rothbard, 2008). Here, the theory of value has been ignored, to imagine a price decline was caused by monetary expansion. Rothbard would join Keynes, Fisher and others in explaining the Depression as a monetary policy failure. Initially, Keynes was a quantity theorist $(1923,1930)$ in the mould of Marshall and Pigou, but only later would alter his views by re-presenting the quantity theory within the mercantilist purchasing power theory (1936). Fisher blamed the gold standards' stable currency for the demise in purchasing power $(1928,1935)$ by using his equation of exchange (1911) in an attempt to show that USD 8.0Bn reduction in the quantity of current account money (from USD 23Bn to USD 15Bn) was the cause of the Great Depression (Fisher, 1935, p. 6). Friedman also blamed the decline in prices due to the decline in the stock of money (Friedman, 1963). Thus we have Austrians, Keynesians, Quantity Theorists and Monetarists, all blaming the Great Depression on monetary policy and the supposed inflexibility of the gold standard. The data tells us that the Great Depression was not a result of monetary policy but rather trade policy. With the price of wheat expressed in USD/bushel, the price is a value of measure of 60 pounds of wheat per bushel of wheat, being equal to the value of exchange of a weight of 23.22 grains of gold, since the dollar before 1934 was defined as weighing 25.8 grains, $9 / 10$ fine, and thus 23.22 grains of pure gold, implying that the price of gold was USD $20.67 /$ FTO (= 480 troy grains per oz/23.22). The price of corn is 
expressed in USD/bushel, with a bushel of shelled corn being equal to $56 \mathrm{lbs}$.

Table 8. The relative values of wheat and corn, America, 1929-1931

\begin{tabular}{ccccc}
\hline & & \multicolumn{2}{c}{ Corn } \\
& USD/Bu & lbs/FTO & USD/Bu & lbs/FTO \\
\hline June 1929 & 1.22 & 1,017 (Note 36) & 0.92 & 1,258 \\
June 1931 & 0.75 & 1,654 & 0.57 & 2,031 \\
& & $63 \%$ & & $61 \%$ \\
\hline
\end{tabular}

Source: Warren (1935).

There was a poor wheat harvest in 1931, but also corn saw one of the worst harvests on record, $26 \%$ smaller as compared to 1929 and the smallest crop in 29 years, and yet, in spite of this short crop, and thus a reduction in supply, as we can observe in table 8 , it still took $61 \%$ more corn to exchange a given weight of gold in 1931 as compared to 1929 (wheat 63\%). With a reduction in supply, why did it take more corn to exchange for gold? America was on a gold standard, and whilst the official value of money was constant, the market price of gold actually decreased slightly by $7 \%$ in 1931, so that the market value of the dollar in terms of gold increased by the same amount. With a fall in nominal commodity prices between $1929-1931$ of $23 \%$, the PPG increased by $30 \%$, but we cannot equate the PPG with the VM, and the difference being the slight rise of about $7 \%$ in the value of the dollar, since its rate of exchange with gold, the PG, had fallen by the same amount.

Table 9. Index values for the price of wheat, commodities and the purchasing power of wheat, 1914 \& 1929 $(1800=1)$

\begin{tabular}{cccc}
\hline & PW & CP & PPW \\
\hline 1914 & 0.54 & 0.77 & 0.70 \\
1929 & 0.57 & 1.08 & 0.53 \\
& 1.05 & 1.40 & 0.75 \\
\hline
\end{tabular}

Source: Historical Statistics, E 123-134, pp. 207-209.

In table 9, with the price of wheat (PW) in 1929 at $5 \%$ of 1914 prices and commodity prices (CP) generally at $40 \%$, then the purchasing power of wheat (PPW) was only $75 \%$ of what it was in 1914 , and therefore had lost $25 \%$ of its purchasing power, implying that wheat was relatively low in price: in fact, we can present the long term PW and the PPW in figure 8.

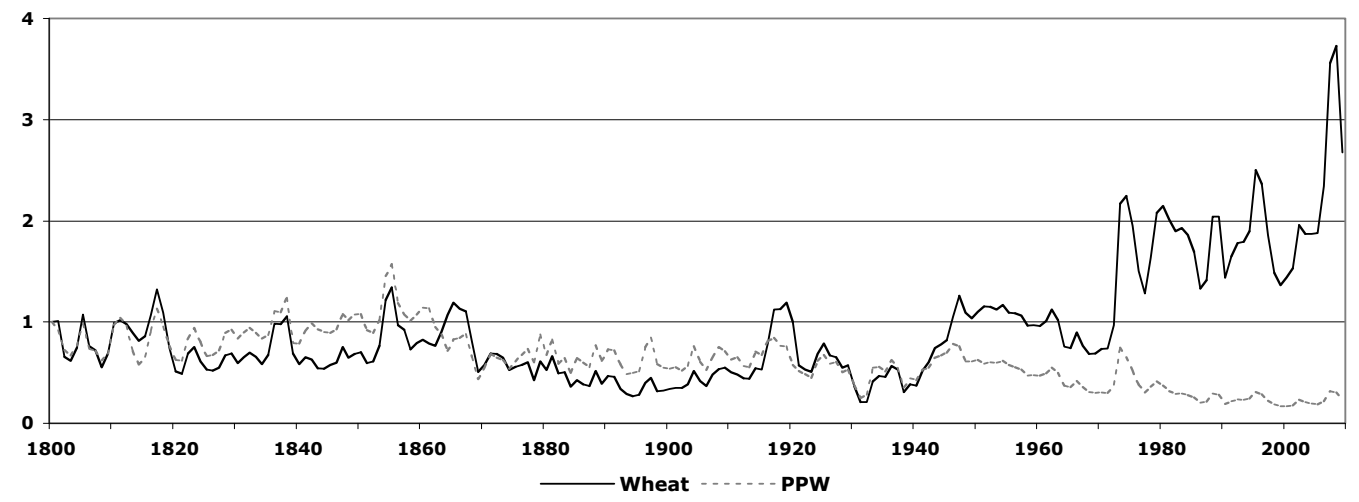

Sources: Historical Statistics (1975 1:207-209, 2006 4:102-4), USDA, Warren (1935:11-15), Bureau of Labor Statistics

Figure 8. Indices of wholesale prices of wheat and the purchasing power of wheat (PPW), America, 1800-2009 $(1800=1)$

The cycles in the PW are due to the variations in the supply and demand for wheat and reflected in the PPW, however, fluctuations in the PW away from the PPW are due the supply and demand of money. The PW might be high in spite of an excess supply of wheat, and if the PPG is low, then the PPW reveals the true position of the 
wheat business in relation to all commodities. If gold was stable in value, the curves for the PW and the PPW would be similar. In fact, in 1931 the curves did coincide, and with both the PG and CP constant, the collapse in $\mathrm{CP}$ resulted in an increase in the PPG, and must have been as a result of the fall in demand for commodities. The fall in demand would represent a fall in agricultural income, and caused an increase in the default rate on loans, and for fractional reserve banks, a reduction in their loan book meant a reduction in banking assets that required an equal reduction in their liabilities in the form of deposits. Banks, businesses and farmers would become insolvent, thereby causing unemployment and deepen the depression. It was not monetary policy that caused the Depression, but rather trade policy compounded by fractional reserve banking.

In figure 9, we may observe that the trigger for Great Depression in terms of unemployment was the Smoot-Hawley tariff legislation, which was enacted in 1930. The interesting factor is that the Wall Street Crash which occurred on the $29^{\text {th }}$ October 1929 , occurred as investors realized that the Smoot-Hawley Act, which had already passed the House of Representatives in May 1929, had sufficient support in the U.S. Senate by $21^{\text {st }}$ and 22 October, so that the market sold off on the $23^{\text {rd }}$ and $24^{\text {th }}$ October, but crashed on $28^{\text {th }}$ and $29^{\text {th }}$ October when investors realized that President Hoover would not veto the bill either. Indeed, it was eventually signed into law in June 1930, despite the fact that 1,027 economists had urged Hoover to veto the bill in May 1930, just one month earlier (Beaudreau, 2005).

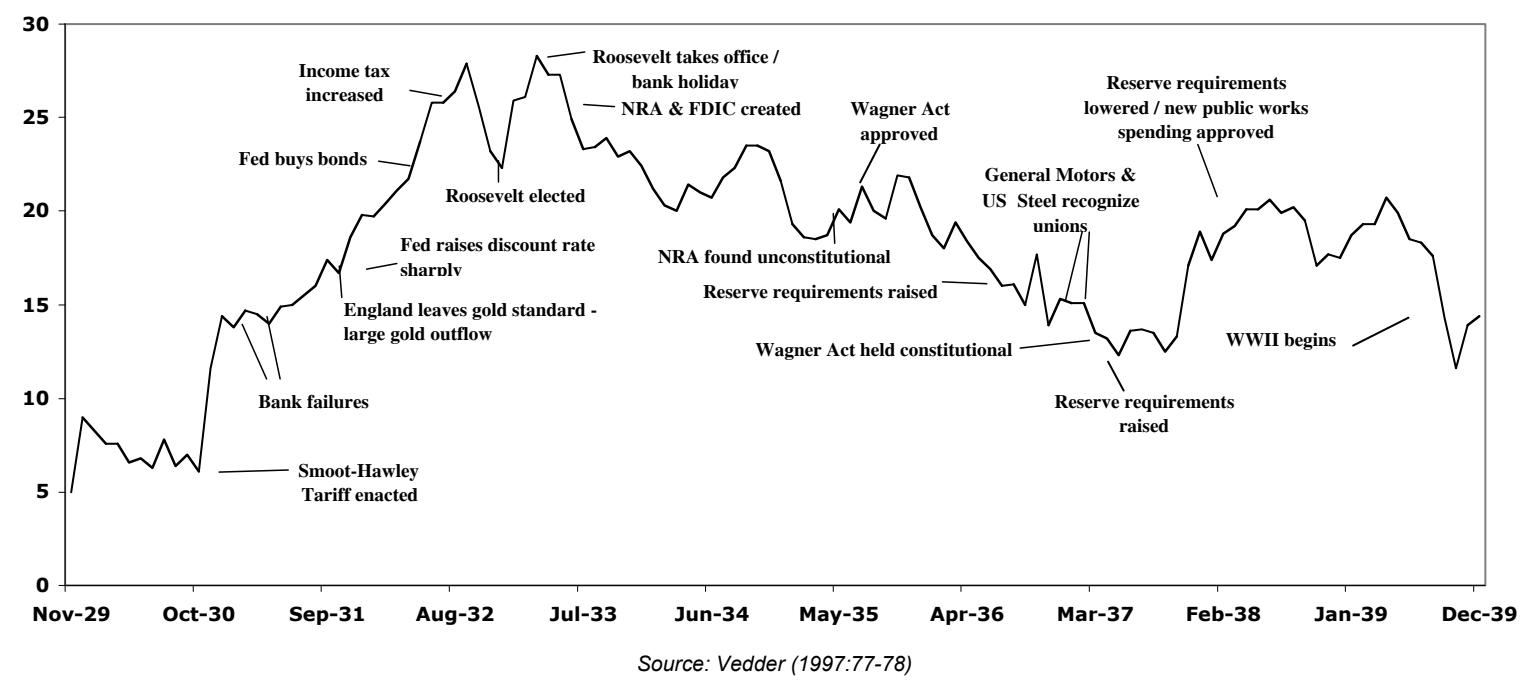

Figure 9. Unemployment during the great recession, immediately following the Oct. 1929 Wall Street Crash

Just after the Wall Street Crash, the unemployment rate was 5\% in November 1929, but had jumped to $15 \%$ by mid 1931. Over 12 million Americans workers or $25 \%$ of the workforce were unemployed by 1934 . According to the National Bureau of Economic Research, GDP fell from USD 101.4 billion in 1929 to USD 68.3 billion in 1933 (1929 dollars), and whilst the Smoot-Hawley tariffs collapsed U.S. imports from USD 4.4 billion in 1929 to USD 1.45 billion in 1933, the resulting retaliatory tariffs collapsed U.S. exports from USD 5.24 billion in 1929, to USD 1.68 billion in 1933. Thus, the Great Depression was not triggered by monetary policy, and thus by implication the gold standard, but it was trade policy and the Smoot-Hawley Tariff Act (Beaudreau, 2005; Vedder, 1997). The result was the end of the classical gold standard with President Roosevelt confiscating all the privately held gold in 1933, only to be subsequently replaced by the Bretton Woods gold exchange system in 1944 and the establishment of the IMF in 1945. Under this system, the dollar took over the role that gold had played under the gold standard, and became the international reserve currency, in the form of a pegged currency regime, so that member nations were required to establish a parity of their national currencies in terms of the dollar as the reserve currency, and maintain exchange rates within a band of plus or minus $1 \%$ of parity, by intervening in their foreign exchange markets. The dollar was linked to gold at USD 35/FTO, the rate at which central banks could exchange dollars for gold. Bretton Woods in reality was system of payments based on the dollar, in which all currencies were defined in relation to the dollar, itself convertible into gold - the dollar was now effectively the world currency, and the standard to which every other currency was now pegged, so that all international transactions thereafter became denominated in dollars. In August 1971, President Nixon unilaterally terminated the convertibility of the dollar into gold, and the dollar became a fiat reserve currency for all other 
currencies.

Rather than backed by the promise of the United States, the monetary balance sheet of the dollar is backed by $1 \%$ gold and $99 \%$ debt. Technically, the U.S. has a gold stock worth USD11,048 million valued at an historical cost of USD 42.2222/oz, or 261,663,296 ozs. By end June 2003, and re-valuing U.S. gold reserves at the prevailing London PM fix of USD347.70/oz, the U.S. gold was worth USD 90.5 billion. Equally, from the Federal Reserve's balance sheet, M3 was USD 8,971.6 billion (table 10). Thus, each dollar is backed by $1 \%$ of gold and $99 \%$ by debt.

Table 10. Monetary balance sheet of the U.S. Dollar (Bns) at June 2003

\begin{tabular}{cccc}
\hline Assets & Value & Liabilities & Value \\
\hline Gold @ $\$ 347.70 / \mathrm{oz}$ & 90.5 & Federal Reserve Notes & 658.9 \\
IOUs Owed to Banks & $8,881.1$ & Bank Deposits & $8,312.7$ \\
& $8,971.6$ & M3 & $8,971.6$ \\
\hline
\end{tabular}

Sources: Federal Reserve Statistical Releases H.4.1 \& H6; U.S. Reserve Assets 3.12.

The Federal Reserve System's 50 ${ }^{\text {th }}$ Anniversary Edition annual report of 1963 stated that, "the function of the Federal Reserve System is to foster a flow of credit and money that will facilitate orderly economic growth, a stable dollar, and long-run balance in our international payments" (Duncan, 2003). Clearly, the Federal Reserve has failed in its strong dollar policy, except for the period at the end of the $20^{\text {th }}$ century-why did the dollar pause before continuing its trend of exponential decay? The answer requires an analysis of the gold market.

\subsection{The Gold Market}

The world is still submerged in a global financial crisis and the dollar is the international reserve currency, but given that the U.S. faces insurmountable fiscal obligations, run-away budget and trade deficits, an un-repayable national debt and an unsustainable credit market, why has the dollar not already collapsed? The answer is that the strong-dollar policy, so often advocated by the U.S. government, involves the dollar value of gold being rigged to give a false impression of the real value of the dollar, which would otherwise have continued its exponential rate of decay in terms of value and thus purchasing power. From the mid 1990s onwards, an explosion of gold derivatives has suppressed the gold price, and exerted enormous downward pressure, such that the gold price has not kept pace with inflation, and whilst the USD1,200/oz high of December 2009 is nominally higher that the last high during the Iran-Iraq war of USD850/oz in January 1980, the inflation adjusted price in constant 2009 dollars should be about USD 2,360/oz (Note 37).

As a former executive of Goldman Sachs in London, Robert Rubin developed an idea to borrow gold from central banks at minimal interest rates of around 1\%, sell the gold for cash and use the proceeds to invest in higher yielding assets and investments to fund Goldman Sachs' operations. Central banks participated, confident that the borrowed gold would be repaid, and this started the gold carry trade. When Rubin became Treasury Secretary he operated an identical carry trade, but on a much larger scale, which became the principle mechanism for the 'strong dollar policy'. Subsequent Treasury Secretaries have reiterated their commitment to the strong dollar policy, implying their continued commitment to feed official gold stocks clandestinely into the market to support the dollar and suppress both interest rates and precious metal prices. If gold swaps are rolled over or expanded, the implication is that the initial gold lent is not being returned. Former Treasury Secretary Larry Summers and successor to Rubin, whilst a Professor at Harvard University, co-authored a study (Barsky, 1988), which concluded that, not only under the gold standard, but under the fiat standard, gold prices move inversely with real interest rates, and conversely, if gold prices were fixed then interest rates can be maintained at lower levels. In figure 10, we present the Gibson's Paradox (Note 38) in America in terms of log real prices or the log inverse price of real gold (Abdullah, April 2013), since the PPG is the inverse of real prices expressed in terms of gold (CPIgc), where the gold value of currency (GC) is the inverse of the currency value of gold (PG), such that real prices are also a function of nominal prices and intrinsic value (6), and real gold is the PPG adjusted by consumer prices (7),

$$
\begin{array}{cc}
\text { Real prices } & \text { CPIgc }=1 / \mathrm{PPG}=\mathrm{GC} \times \mathrm{CPI} \\
\text { Real gold } & \mathrm{PPG}=\mathrm{PG} / \mathrm{CP}
\end{array}
$$

Real prices (CPIgc) are presented together with real interest rates $(r)$, being the nominal rate of interest reflected in the yield of 10 year Treasury bills $(i)$, less the annualized rate of inflation derived from the CPI $(\pi)(8)$, 


$$
r=i-\pi
$$

As with Gibson's Paradox in England under a gold standard, a fall in the price level corresponded with a decline in interest rates (reflected in the yield on Consols), and with a gold price that was fixed, the PPG thereby increased. Under a U.S. fiat standard, falling real yields make holding financial assets less attractive, whilst rising real interest rates increase the opportunity cost of holding gold (with zero or minimal yield), hence the price of gold rises as the attraction and confidence in financial paper assets declines.

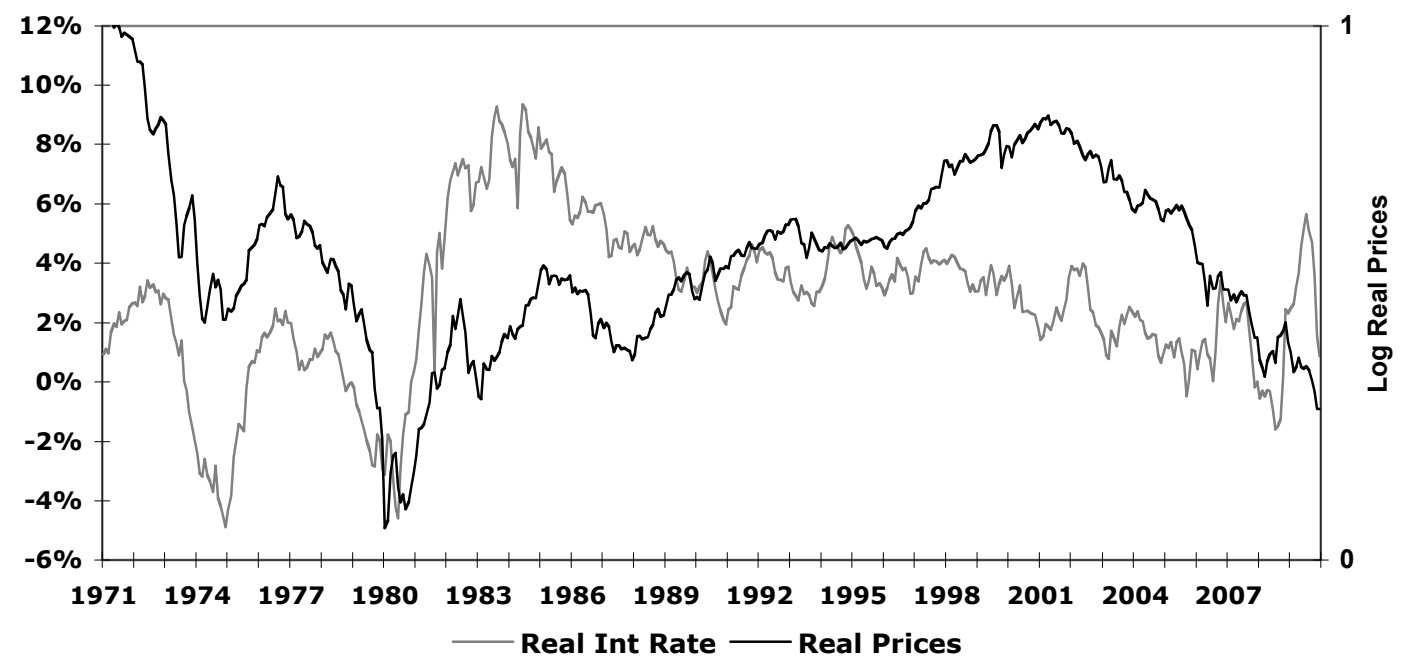

Sources: Federal Reserve Statistical Release H.15, BLS, WGC

Figure 10. Gibson's paradox in the United States, 1971-2009, Log real prices and real interest rates

There is a clear correlation between the general trend of real interest rates and the co-movement in real prices, which "comes out of hiding as real yields on financial assets decline and especially as the risk of a financial crisis in terms inflation or deflation rises. As the risk rises, the role of gold as 'true' money and a store of value re-asserts itself. In essence, gold acts as a barometer of the financial attraction and confidence level of paper money" (Mylchreest, 2006).

Interestingly, the former Federal Reserve Governor, Wayne Angell, in an FOMC meeting, explained that, "the price of gold is pretty well determined by us...but the major impact on the price of gold is the opportunity cost of holding the U.S. dollar...We can hold the price of gold very easily; all we have to do is to cause the opportunity cost in terms of interest rates and US Treasury bills to make it unprofitable to own gold" (FOMC, 1993).

When real rates of return are negative and sovereign debt is not only being downgraded (the U.S.) but questioned altogether (Euro-zone), we can expect higher gold and silver prices, for bullion does not have any counter-party risk. In summary for America, it was not debasement of the gold or silver dollar, but the over-valuation of gold within a bimetallic standard, and the operation of a fractional reserve gold standard, that inevitably led to an exponential decay of dollar under the fiat standard, as a result of an excessive supply of money in relation to demand, the effect of which was to increased prices, as reflected in figure 11. 


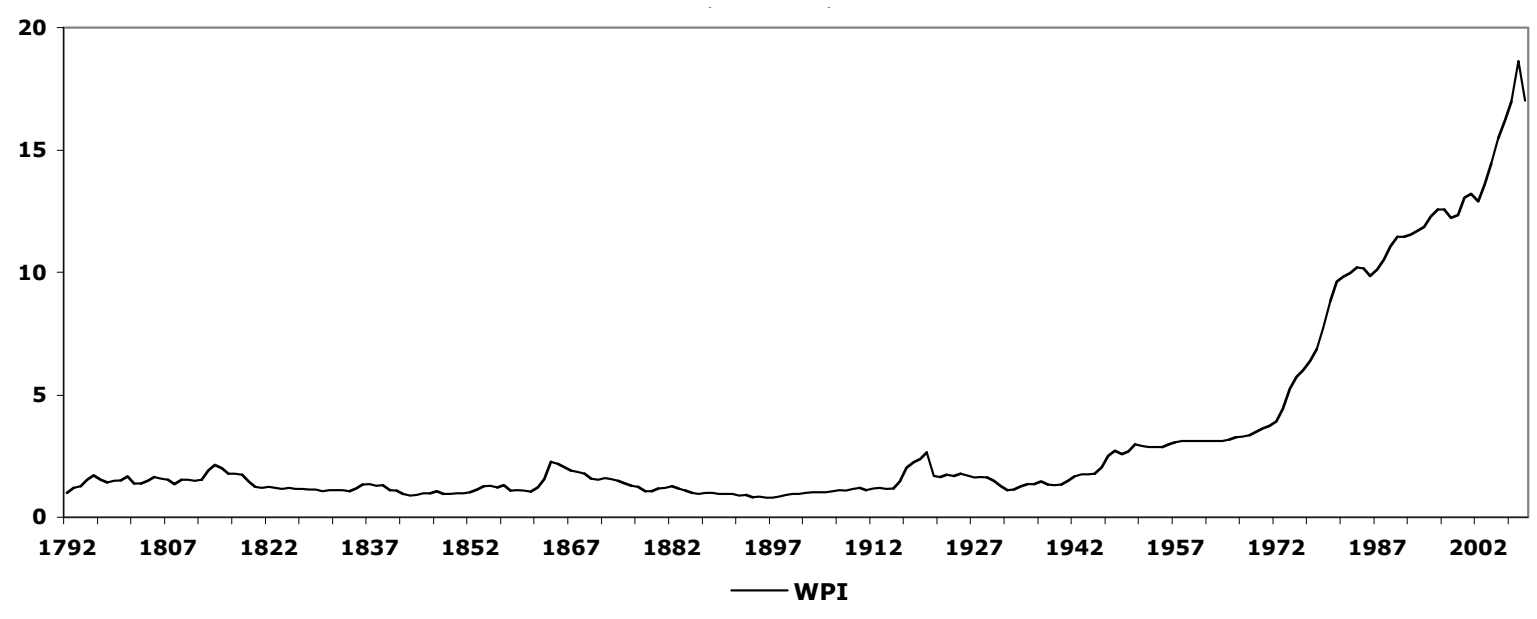

Sources: Warren (1935:11-15, 1933:10-13), Bureau of Labor Statistics

Figure 11. Index of wholesale commodity prices, America, 1792-2009 (1792=1) (linear scale)

Value (as reflected in the PG or GC), supply and demand of money, exactly reflects a monetary theory of value. We also present in figure 12, wholesale commodity prices in terms of grams of pure gold (CPgc), in order to establish what prices would have been, had the value of the dollar been maintained in terms of gold.

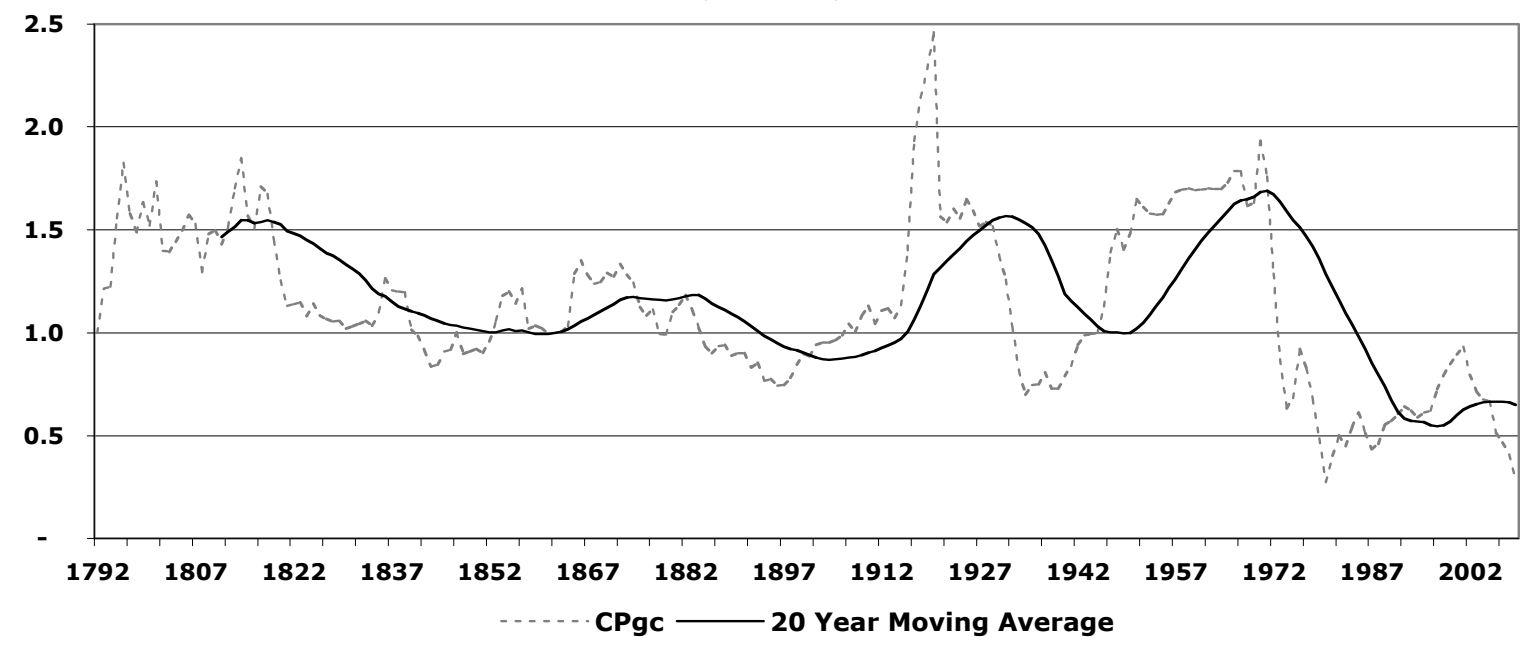

Sources: (PG) - HCL, PP, L, SP, LBMA; (X-rates) - W, O ; (CP) - WP, BL.

Figure 12. Wholesale commodity price index adjusted by the New York market price in grams of pure gold (GCPgc), America, 1792-2009 (1792=1) (linear scale)

There are short-term movements in prices when expressed in gold, which were within a narrow range of 0.25 up to 2.5, and revolved a long-term trend than was constant, even though nominal prices rose by 19 times. We can also present the PPG and the CPgc in log scale (figure 13), in order to observe how the VM clearly affects CP. Given the identity $\mathrm{PPM}=1 / \mathrm{P}$, and since gold is money, $\mathrm{PPG}=1 / \mathrm{CPgc}$. Clearly the $\mathrm{CPgc}$ is remarkably stable. 


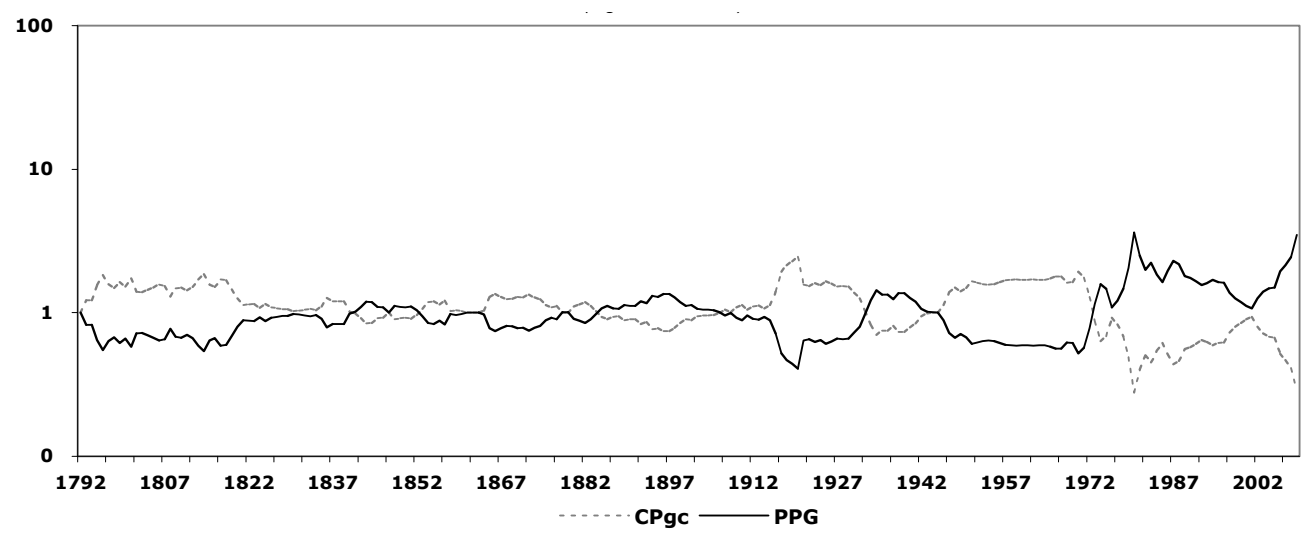

Sources: (PG) - HCL, PP, L, SP, LBMA; (X-rates) - W, O ; (CP) - WP, BL:

Figure 13. Indices of wholesale commodity price in grams of pure gold (CPgc), and the purchasing power of gold (PPG), America, 1792-2009 (1792=1) (linear scale)

We also present in figure 14, wholesale commodity prices in terms of grams of pure silver (CPsc), in order to establish what prices would have been, had the value of the dollar been maintained in terms of silver. What is impressive is that there are short-term movements in prices when expressed in silver, which were within a narrow range of 0.9 up to 2.0 , only to widen within a range from 0.55 to 6.10 , not after the de-monetization of silver from 1873, when dollar notes would only be redeemed in gold and yet silver coins remained in circulation, but after the enactment of the gold standard in 1900 and the subsequent breakdown of monetary order in the $20^{\text {th }}$ century. Nonetheless, prices in silver also revolved around a long-term trend than was constant, even though nominal prices, as mentioned earlier, rose by 19 times.

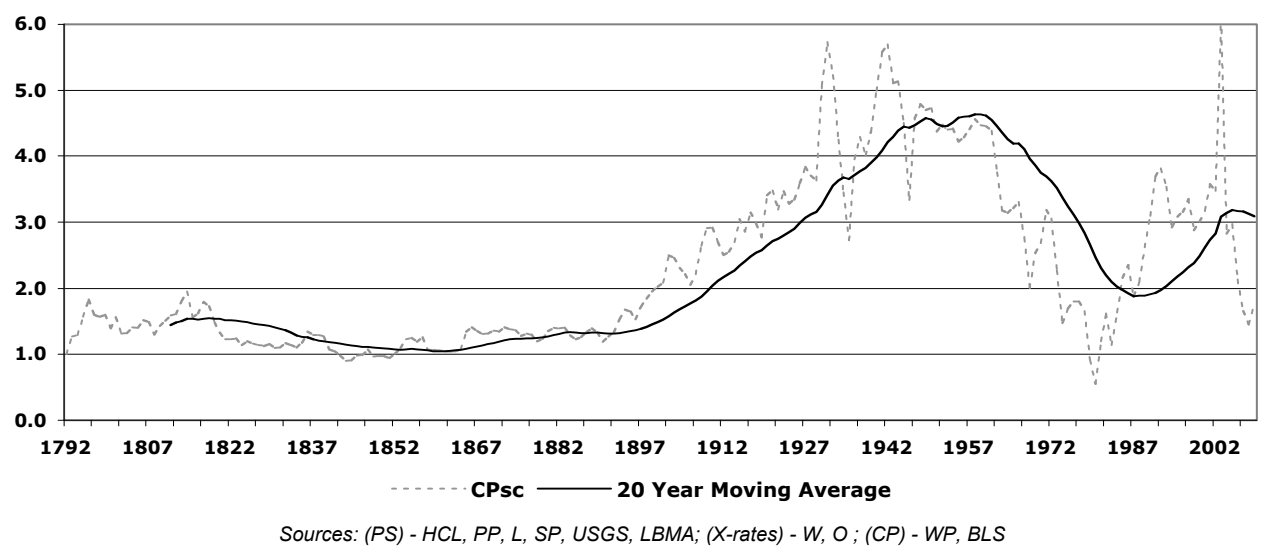

Figure 14. Wholesale commodity price index adjusted by the New York market price in grams of pure silver (CPsc), America, 1792-2009 (1792=1) (linear scale)

In figure 15 , we similarly present the data on silver, in terms of real silver (PPS) and the real prices (CPsc) in log scale, in order to observe how the VM clearly affects CP. Given the identity PPM $=1 / \mathrm{P}$, and since silver is money, $\mathrm{PPS}=1 / \mathrm{CPsc}$. Clearly, the CPsc is also stable over the long term. 


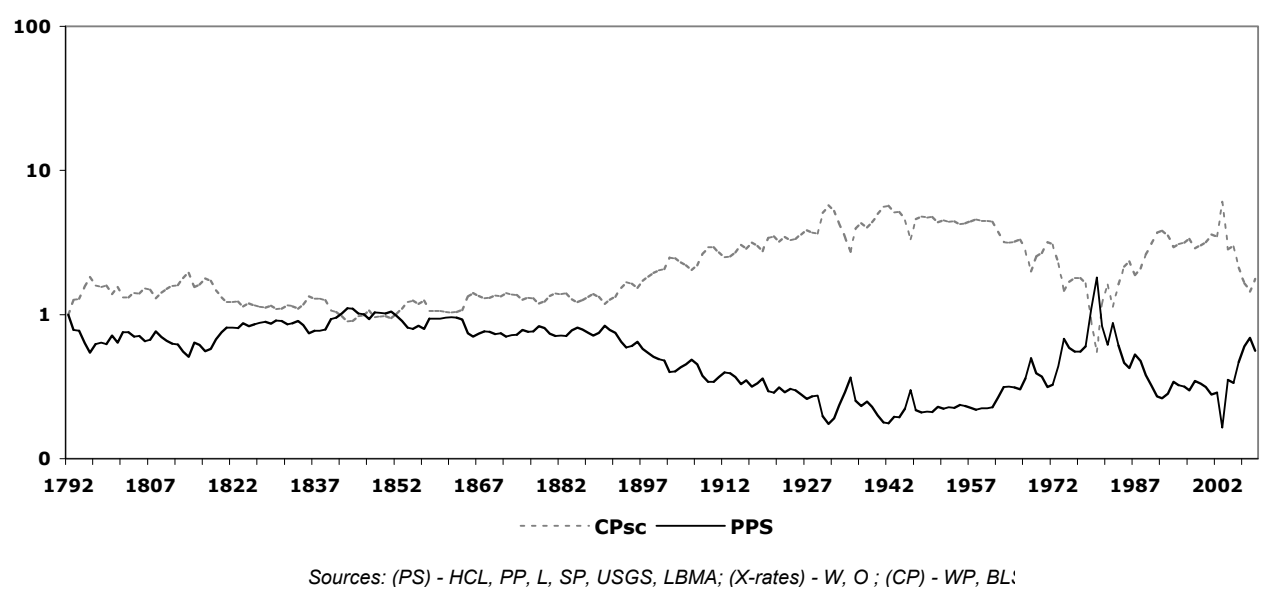

Figure 15. Indices of wholesale commodity price in grams of pure silver (CPsc), and the purchasing power of silver (PPS), America, 1792-2009 (1792=1)

The correlation between the PG and CP in America between 1792-2009 is 0.93, which implies that the decrease in the VM (i.e. an increase in the PG) is strongly correlated with CP. This paper has further demonstrated that the causal significance and required adjustment to the VM that effects the PPM and in CP, is arrived at by expressing real prices (CPgc, CPsc) over the long term, and when multiplying real prices by the PPG or PPS, such that CPgc $\mathrm{x}$ PPG (or CPsc $\mathrm{x} P P S)=1$. This demonstrates that any reduction in the VM is proportional to the increase in CP. When the VM is held constant, real prices (CPgc, CPsc) and real money (PPG, PPS) may fluctuate over the short term, but revolve around a long-term secular trend that is also constant.

\subsection{Performance Analysis}

When we assess short-term volatility, prices expressed in real terms reveal factors associated with other than monetary distortion. Such factors can include political, social and economic issues, the latter including shocks to the economy due to the monetary system resulting in a mis-allocation of resources. For America from 1792-2009, $\sigma$ was $8.3 \%$ for $\mathrm{CPgc}$ and $13.0 \%$ for CPsc, and prior 1914 it was $5.4 \%$ and $5.5 \%$. Volatility was more pronounced during the $20^{\text {th }}$ century and the evident breakdown of monetary order. By applying the criteria of long-term price stability and short-term volatility to America (table 11), the international gold standard was the most stable, whilst the greenback dollar was the least stable due to paper inflation that financed the civil war, followed by a proportional deflation in order to resume the de facto gold standard. In reality the inter-war gold-exchange standard included the departure from the gold standard in 1933, and the fractional reserve Bretton Woods gold-dollar exchange standard would prove unsustainable in the face of U.S. budget and trade deficits. Clearly, the worst performing system in terms of long-term stability if the current fiat paper standard averaging $4.2 \%$ p.a. from 1971 to 2009: in contrast, by correcting the value of money, when prices are expressed in gold $(\mathrm{CPgc})$, from $1792-2009$, the average annual change is only $0.1 \%$ over the entire period. 
Table 11. Wholesale price index, America: Long-term stability and short-term volatility

\begin{tabular}{|c|c|c|c|c|c|}
\hline Period & Monetary System & $\begin{array}{l}\text { Long-Term } \\
\text { Stability }\end{array}$ & $\begin{array}{c}\text { Short-Term } \\
\text { Volatility }\end{array}$ & $\begin{array}{c}\text { Stability } \\
\text { Rank }\end{array}$ & Comments \\
\hline $1792-1834$ & $\begin{array}{c}\text { domestic silver standard (includes War } \\
\text { of 1812-1815 and domestic paper } \\
\text { standard 1814-1817) }\end{array}$ & $0.6 \%$ & $6.1 \%$ & 3 & $\begin{array}{l}\text { fractional reserve silver } \\
\text { standard }\end{array}$ \\
\hline $1834-1861$ & $\begin{array}{l}\text { domestic gold standard (de facto from } \\
\text { 1834; includes domestic paper } \\
\text { standards } 1837-1843 \text { and } 1857 \text { ) }\end{array}$ & $0.1 \%$ & $4.7 \%$ & 2 & $\begin{array}{c}\text { fractional reserve gold } \\
\text { standard }\end{array}$ \\
\hline $1862-1879$ & $\begin{array}{l}\text { domestic paper standard (civil war \& } \\
\text { Greenback paper dollars } 1862-1878, \\
\text { silver de-monetized from 1873) }\end{array}$ & $0.9 \%$ & $11.0 \%$ & 5 & $\begin{array}{l}\text { civil war inflation offset by } \\
\text { silver demonetization }\end{array}$ \\
\hline $1879-1914$ & $\begin{array}{l}\text { international gold standard (de jure } \\
\text { from 1900) }\end{array}$ & $0.4 \%$ & $3.1 \%$ & 1 & $\begin{array}{c}\text { fractional reserve gold } \\
\text { standard }\end{array}$ \\
\hline 1914-1944 & $\begin{array}{l}\text { inter-war gold standard (domestic } \\
\text { paper standard from } 1933 \text {, U.K. off } \\
\text { gold standard 1914-1925 and from } \\
\text { 1931) }\end{array}$ & $2.0 \%$ & $9.3 \%$ & 5 & $\begin{array}{c}\text { about } 60 \% \text { on a gold } \\
\text { standard: } 1930 \text { s deflation }\end{array}$ \\
\hline 1944-1971 & Bretton Woods gold-dollar standard & $2.9 \%$ & $5.1 \%$ & 4 & $\begin{array}{l}\text { fractional reserve gold } \\
\text { exchange standard }\end{array}$ \\
\hline 1971-2009 & international fiat paper dollar standard & $4.2 \%$ & $4.3 \%$ & 4 & $\begin{array}{l}\text { fractional reserve debt as } \\
\text { money }\end{array}$ \\
\hline
\end{tabular}

\section{Conclusion}

In the preceding sections, we have analyzed the value and purchasing power of money over the long term in America over 218 years from 1792-2009. Our findings found that gold and silver both retain their purchasing power over the long term, whilst paper money in terms of the international fiat paper dollar, failed a basic function of money in retaining its store of value. This paper has demonstrated that devaluation was the primary cause in the decline of the VM and thus the PPM. Hence, a monetary theory of value stipulates that a reduction in the VM (reflected in its rate of exchange with a precious metal), as a result of an excessive increase in nominal money supply in relation to demand, the effect (and not the cause) is an increase in prices. In essence, there is an inverse relationship with rate of decay in the VM through devaluation and higher nominal prices. By correcting the loss of the VM, we obtain not only constant real prices expressed in bullion, the reciprocal of which is a constant PPG or PPS, and for "a currency, to be perfect, (it) should be absolutely invariable in value" (Ricardo, 1816). Monetary policy should not target stable prices by devaluing the PPM, as reflected in current macroeconomic thinking, but should maintain a stable currency, free from manipulation by monetary authorities, in order to achieve a stable PPM and thus stable CP over the long term. In particular, our empirical evidence has demonstrated that the classical quantity theory and the Keynesian purchasing power theory, have both been responsible for influencing monetary theory and policy, involving a medium of exchange that is now no longer anchored to intrinsic value through the backing of gold or silver, but is instead backed by assets of the banking system, being debt at interest. However, these monetary theories have led to the same macroeconomic result under the fiat standard since 1971, which is exposed when we express this in terms of a monetary theory of value: an exponential decay in the VM, due to excessive debt and money creation in relation to demand, the effect of which has led to an exponential increase in nominal prices, but when corrected for this loss of value, real prices are both low and constant. Modern cross rates of exchange between nations in international trade simply reflect a race to the bottom in terms of devaluation. In reality, the resource cost of fiat money is reflected in the combined profit and loss statements of the fractional reserve banking system, which is a direct beneficiary, requiring societies to lower their standard of living, through increased prices and transferring wealth to the issuers of money (in this case the banks operating as private mints): "the decrease in purchasing power incurred by holders of money due to inflation imparts gains to the issuers of money" (Reubling, 1975), that involves wealth "confiscation through inflation. There is no safe store of value...no way for the owners of wealth to protect themselve Gold (or silver) stands in the way of this insidious process" (Greenspan, 1966).

\section{References}

Abdullah, A. (2013, April). The gibson paradox: Real gold, interest rates and prices. International Business Research, 6(4), 32-44. http://dx.doi.org/10.5539/ibr.v6n4p32

Abdullah, A. (2013, March). Examining the value of money in England over the long term 1259-2009. International Journal of Economics and Finance, 5(3), 73-89.

Barsky, R. B., \& Summers, L. H. (1988). Gibson's paradox and the gold standard. The Journal of Political Economy, 96(3), 528-550. http://dx.doi.org/10.1086/261550 
Beaudreau, B. C. (2005). How the republicans caused the stock market crash of 1929, GPTs, failed transitions and commercial policy. Lincoln, NE: iUniverse Inc.

Beveridge, W. (1965). Prices and wages in England from the twelfth to the nineteenth century. London: Longmans Green \& Co.

Bureau of Labor Statistics. (2012, December 20). Retrieved from http://www.bls.gov

Castaing, J. (2007). The course of the exchange and other things, 1698-1823. Guildhall Library.

Clark, G. E. H. (1894). Shylock: As banker, bondholder, corruptionist, conspirator. Washington D.C.: American Bimetallic League.

Clarke, T. G. (1974). Silver. Ecology and Natural Resources Collection, 1, 1181-1199. Retrieved from http://digicoll.library.wisc.edu/cgi-bin/EcoNatRes/EcoNatRes-idx?type=article\&did=EcoNatRes.MinYB197 4v1.CKlingman3\&id $=$ EcoNatRes.MinYB1974v1\&isize $=\mathrm{M}$

Duncan, R. (2003). The dollar crisis. Singapore: John Wiley \& Sons.

Federal Reserve. (2012, December 20). Statistical releases \& historical data, selected interest rates H.15. Retrieved from http://www.federalreserve.gov/release/h15/data.htm

Fenton, R. E. (2010). International monetary conference. Washington, DC: Government Printing Office.

Fisher, I. (1911). The purchasing power of money. New York: Macmillan.

Fisher, I. (1922). The making of index numbers: A study of their varieties, tests, and reliability. Boston: Houghton Mifflin Company.

Fisher, I. (1935). 100\% Money. New York: Adelphi.

FOMC. (1993, July 6-7). Minutes recorded for the Meeting of the Federal Reserve Open Market Committee.

Frankel, H. (1953). The price of gold and the purchasing power of the pound sterling. Journal of the Royal Statistical Society, 116(1), 35-46. http://dx.doi.org/10.2307/2980948

Friedman, M., \& Schwartz, A. J. (1963). A monetary history of the united states, 1867-1960. New York: National Bureau of Economic Research.

Gallatin, A. (2008). Considerations on the currency and banking system of the United States. Philadelphia: Carey and Lea 1831. (Reprinted Whitefish MT: Kessinger Publishing).

Gibson, A. H. (1923, January). The future of high class investment values. Bankers', Insurance Managers'and Agents'Magazine, 15-23.

Gibson, A. H. (1926, November). The road to economic recovery: Some reflections. Bankers', Insurance Managers' and Agents' Magazine, 595-612.

Greenspan, A. (1966). Gold and economic freedom. The Objectivist Newsletter. Retrieved from http://www.321gold.com/fed/greenspan/1966.html

Harvey, W. H. (1894). Coin's financial school, coin financial series, issued quarterly. Chicago: Coin Publishing Company.

Historical Statistics. (1975). Historical statistics of the United States, Colonial Times to 1970. Washington, D.C.: U.S. Bureau of the Census.

ILO-PPI. (2004). Producer price index manual: Theory and practice. Geneva: International Labour Office.

Jastram, R. W. (1977). The golden constant, the English and American experience 1560-1976. New York: John Wiley \& Sons.

Jastram, R. W. (1981). Silver, the restless metal. New York: John Wily \& Sons.

Keynes, J. M. (1923). A tract on monetary reform. London: Macmillan. (Republished from New York: Prometheus, 2000).

Keynes, J. M. (1930). A treatise on money. London: Macmillan. (Reprinted, 1958).

Keynes, J. M. (1936). The general theory of employment, interest and money. (Republished from the Royal Economic Society, Basingstoke: Palgrave Macmillan, 2007).

LBMA. London Bullion Market Association. (2013). Retrieved from http://www.lbma.org.uk/pages/index.cfm Leavens, D. H. (1939). Silver Money. Bloomington, Indiana: Principia Press. 
Li, M. H. (1963). The great recoinage of 1696 to 1699. London: Weidenfeld and Nicolson.

Marshall, A. (1920). Principles of economics. New York: Cosimo.

Marshall, A. (1923). Money, credit, and commerce. London: Macmillan. (Reprinted from New York: Prometheus, 2003).

Mitchell, W. C. (1965). The making and using of index numbers. New York: Augustus M. Kelley.

Mueller, J. D. (2010). Redeeming economics, rediscovering the Missing Element. Wilmington, Del.: ISI Books.

Mullins, E. (1983). The secrets of the federal reserve. Staunton, Virginia: Bankers Research Institute.

Mylchreest, P. (2006, January). Metals and mining, sector report. Crédit Agricole Cheuvreaux International Ltd. Retrieved from www.gata.org/files/CheuvreuxGoldReport.pdf

Neal, L. (1996). Course of the Exchange, London, 1698-1823 and Amsterdamsche Beurs, Amsterdam, 1723-1794.

Officer, L. H. (2007). Between the dollar-sterling gold points, exchange-rates, parity, and market behavior. Cambridge: Cambridge University Press.

Officer, L. H. (2013-a). The price of gold 1257-present. What was the price of gold then? A data study. Measuring Worth. Retrieved from http://www.measuringworth.org/gold/

Officer, L. H. (2013-b). Dollar-pound exchange rate from 1791. Measuring Worth. Retrieved from $\mathrm{http}: / /$ www.measuringworth.org/exchangepound/

Pigou, A. C. (1917, November). The value of money. Journal of Economics, 32(1), 38-65.

Ricardo, D. (1816). Proposals for an economical and secure currency: With observations on the profits of the bank of England, as they regard the public and the proprietors of bank stock. London: John Murray.

Ricardo, D. (2004). The principles of political economy and taxation. London: J. M. Dent \& Sons. (Reprinted from New York: Dover Publications).

Ronk, S. E. (1934, September). Prices received by producers in New York State 1841-1933.

Rothbard, M. N. (1983). The mystery of banking. New York: Richardson \& Snyder.

Rothbard, M. N. (2008). America's great depression. Auburn, Alabama: Ludwig von Mises Institute.

Ruebling, C. E. (1975, February). Financing government through monetary expansion and inflation. Federal Reserve Bank of St. Louis Review, 15-23.

Shrigley, I. M. (1935). The Price of gold, documents illustrating the statutory control through the bank of England of the market price of gold, 1694-1931. London: P. S. King \& Son.

U.S. Geological Survey. Commodity Statistics and Infiormation. Gold and Silver, 1. Retrieved from http://minerals.usgs.gov/minerals/pubs/commodity/

United States Department of Agriculture. Economic. Research Services, Wheat Data. Retrieved from http://www.ers.usda.gov/data-products/wheat-data.aspx\#.Ugs7hlP8w6g

Vedder, R., \& Lowell, E. G. (1997). Out of work: Unemployment and government in twentieth century america. New York: Holmes and Meier Publishers.

Von Mises, L. (1981). The theory of money and credit. Indianapolis: Liberty Fund.

Walsh, C. M. (1901). The measurement of general exchange-value. London: Macmillan.

Warren, G. F., \& Pearson, F. A. (1935). Gold and Prices. New York: John Wiley \& Sons.

World Gold Council. (2013). Retrieved from http://www.gold.org

Notes

Note 1 . The currency price of gold $=(100 /(100-10.375)=\$ 1.11576$, or $111.576 \phi$. The market price of gold $=$ $19.3939 \times 1.11576=\$ 21.6389 / \mathrm{oz}$. The gold price of currency $=(100-10.375)=89.625 \phi$, or $\$ 0.89625$; or, the gold price of currency $=(19.3939 / 21.6389)=\$ 0.89625$.

Note 2. The currency price of silver $=\$ 1.11576$, and thus the market price of silver $=(1.2929 / 1.11576)=$ $\$ 1.44257 /$ oz. The silver price of currency $=(1.2929 / 1.44257)=\$ 0.89625$.

Note 3. Exchange rate sources from 1792-1829 White (Fenton, 1879, pp. 634-641, Table BB-no.1), thereafter Officer (2007, pp. 60-98, 2013-b). 
Note 4. Warren (1935, pp. 153-155) cites the official price, being the market price available to private parties. Jastram (2009, pp. 323-330) also quotes annual London market prices converted into dollars at prevailing exchange rates per standard troy oz ( 0.917 fine).

Note 5. Prior to 1878 the price of gold is based on the currency value of gold and the grains of gold in the dollar. Officially, in 1792 the dollar was defined as 416 grains of standard silver $(89.243 \%$ silver) or 27 grains of standard gold (with alloy of $1 / 12$ or $22 \mathrm{k}$ gold): thus the dollar was equivalent to 371.25 grains of fine silver or 24.75 grains of fine gold, so the price of pure silver was $\$ 1.2929 / \mathrm{oz}$ (480 troy grains/371.25), and the price of pure gold was $\$ 19.3939 / \mathrm{oz}$ (480 troy grains/24.75) reflecting a gold:silver ration of 15:1. In 1834 the gold standard was modified to 23.2 grains altering the gold:silver ratio to $16: 1(371.25 / 23.2)$. In 1837, the proportion of alloy in both gold and silver coins was made equal at $10 \%$, so the weight of the silver dollar was reduced to 412.5 grains with 371.25 grains of silver, the gold dollar weighed 25.8 grains with 23.22 grains of gold, hence the gold standard was adjusted to 23.22 grains of pure gold fixing the price of gold to USD20.67/oz $(480 / 23.22=20.67)$ altering the gold:silver ratio to $15.99: 1(371.25 / 23.22)$.

Warren's source for the market price during the 1st suspension of specie payment during 1814-17 was Gallatin (1831:106); from 1837-43 during the 2nd suspension of 1937-38 was Warren (1932, table 30); during the 3rd suspension in 1857 was Ronk (1934,); and during the 4th suspension from 1862-78 (during and immediately following the American civil war of 1861-65) Warren's source is Mitchell (1908,) whom provides the market price of gold in greenbacks.

Note 6. On 12th September 1919 the first gold price "fixing" was held at the offices of N.M. Rothschild's. The price of gold was then quoted for 995 (99.5\% pure) "good delivery" instead of 917. From 1919 the average "fix" price although quoted in GBP reflected the GBP-USD rate in New York.

Note 7. Defined as the U.S. official price at which the Treasury or the Federal Reserve transacted with private parties. Jastram (2009) cites the London market price of gold converted into dollars at prevailing exchange rates, which fluctuated near the U.S official price. Friedman (1963) points out that the weight of the gold dollar was 25.8 grains of standard gold 0.900 fine, thus containing 23.22 grains of fine gold. 1 troy oz $=480$ grains of fine gold, thus 480/23.22 = USD20.67. Under executive order 6102 signed on 5th Apr.1933, President Roosevelt confiscated all privately held gold at USD20.67 to be delivered to Federal Reserve Banks latest 1st May 1933, and the "nationalization" of gold was completed by order of the Secretary of the Treasury dated 28th December 1933 with all remaining stocks outside of the Federal Reserve Banks to be also delivered at \$20.67/oz. Under the Gold Reserve Act of 30th Jan.1934, Roosevelt then fixed the price of gold at USD35/oz or 15.238 grains of standard 0.900 gold containing 13.714 grains of pure gold, or 480/13.714 = USD35, thus devaluing the gold dollar by $41 \%$, or to $59.06 \%$ (13.714/23.22 grains) of its previous value, whilst creating a USD3Bn paper profit, of which USD2Bn was assigned to the Exchange Stabilization Fund authorizing the Secretary of the Treasury to deal in gold, foreign exchange, securities and other credit instruments for the purpose of stabilizing the exchange value of the dollar.

Note 8. Following the Presidential proclamation on 31st January 1934, the function of buying gold from domestic origin had already been transferred to the Federal Reserve Banks on 16th January 1934, and all newly minded domestic gold, un-melted scrap gold, and imported gold was purchased at $\$ 35$ less 1/4 of one percent (\$34.9125) per FTO less mint charges. Thus gold bars were purchased from all comers at $\$ 34.9125$, but gold was sold only to licensed domestic industrial users and to foreign monetary authorities, at $\$ 35$ plus $1 / 4$ of one percent (\$35.0875) per FTO. So the average U.S. official price was $\$ 35 / \mathrm{oz}$ for the period 1st February 1934 to 17 th March 1968, and the market price reflected or fluctuated near the U.S official price during this period.

Note 9. The London Bullion Market Association gold price data is from London Gold Market Fixing Ltd.

Note 10. On 18th March 1968, a free market for gold bars in the New York market was established, although the London market still "fixed" its price but now in USD and introduced an afternoon (pm) fix to take into account of New York, and from 1968 the price is the annual average "pm fix". USGS also cite Platt's Metals Week for prices from 1968-1998. World Gold Council also publishes average monthly prices from 1971 and average annual prices from 1900 in GBP and USD. LBMA quotes average daily and monthly "fix" prices in GBP and USD for both gold and silver from 1968. The WGC publishes average monthly prices from 1971 and average annual prices from 1900 in GBP and USD. Kitco quotes annual prices from 1833 in USD.

Note 11. John Houghton's A Collection for Improvement of Husbandry and Trade quoted gold and silver prices from 1693-1697 (Li, 1963). Castaing's The Course of the Exchange and Other Things included the market price per oz of standard 22k gold in £s and Spanish pieces of eight silver in pennies. It was first published in 1698 and became the forerunner of the London Stock Exchange's Daily Official List. The Lloyds News was established in 
1696 by Edward Lloyd, and was the forerunner of the Lloyds List, which was published from 1734, and also quoted twice-weekly prices including gold and silver from 1735. Castaing's original folios available from the Guildhall Library (see Castaing) and Jastram (2009).

Note 12. Standard gold (or 'crown') gold was 917 gold or $91.7 \%$ pure (22 karat).

Note 13. Jastram (2009).

Note 14. Jastram (2009).

Note 15. Rothschilds became the exclusive bullion broker to the Bank of England in 1825 (Jastram, 1977, p. 24). The first bullion brokers were Mocatta and Goldsmid with Moses Mocatta starting in 1671.

Note 16. Jastram (2009); Shrigley (1935) quotes market gold:silver ratios from 1687-1932, actual gold prices from 1870-1932, actual silver prices from 1833-1933; source for both Jastram \& Shrigley is Sharps, Pixley (Pixley \& Abell).

Note 17. London Bullion Market Association gold price data is from The London Gold Market Fixing Ltd.

Note 18. Defined as the official price of silver available between private parties and remained unchanged at USD1.2929 per FTO, except during periods of bank note depreciation when specie payments were suspended (1) 1814-1817, (2) 1837-1843, (3) 1857, (4) 1862-1878. (Warren, 1935:156) (Officer, 2007). Jastram provides prices from 1800-1925 with source as Director of the Mint Reports, Annual Reports (Jastram, 1981, pp. 164-188, 204-5), but from 1800-1873 are London market prices converted to dollars at prevailing exchange rates per FTO, which would reflect any note depreciation, and from 1874 are New York market prices per FTO.

Note 19. From 1792-1873 there were no New York quotations and no meaningful silver market under the bimetallic standard, until after silver was de-monetized in 1873 (Clarke, 1974) (Leavens, 1939, pp. 8,10). Any transactions in New York between buyers and sellers and their brokers were not as organized as the London market. The "official" market price set by Handy \& Harman that originally reflected the London price but was later based on actual prices in New York, usually at $1 / 4 \%$ below the market given its principle function as a basis for settlement between mines and smelters (Leavens, 1929) and 1/4\% being the difference between refined and unrefined silver (Clarke, 1974).

Note 20. USGS prices per FTO to 5 decimals are available back to 1874 as per Minerals Yearbook (Clarke, 1974, p. 1196) with Mint Reports as the source. Warren and Pearson provide prices of silver bars at New York from 1874-1934 in USD per FTO (3 decimal places), derived from the U.S. Treasury from 1874-89, prices from 1890-34 were derived from the Course of Wholesale Prices 1890-1901, Bulletin of the Department of Labor, No.39, pp. 406-7, March 1902, and following issues (Warren, 1935:257). Warren's prices are preferred for 1874-1878, since the Mint Report prices are under-stated being the silver value of currency (i.e. already adjusted for depreciation), whilst Warren's remaining Dept. of Labor prices from 1879 are very similar to the USGS Mint Report prices. Bureau of Mines provides prices for 1900-1998 with sources 1900-1974 Clarke (1974), 1974-1993 Metals Week, 1993-1998 Platts's Metals Week. Jastram also provides prices from 1925-1975 with source as Bureau of Mines (USGS) Minerals Yearbooks (Jastram, 1981, pp. 164-188, 204-5).

Note 21. Under the Silver-Purchase Proclamation of 21 st Dec.1933 newly mined silver was acquired at $\$ 1.2929 / \mathrm{oz}$ less $50 \%$ seigniorage or a mint equivalent price of 64.65 cents (about a $24 \%$ premium to the market price of 49 cents, thereby ensuring all production would be purchased by the Treasury). Following Roosevelt's recommendations to Congress on 22nd May 1934, The Silver Purchase Act of 19th June 1934 required the purchase of silver from home and abroad until the market price reached $\$ 1.2929 / \mathrm{oz}$, or until the monetary value of the silver stock held by the Treasury reached $1 / 3$ rd of the monetary value of the gold stock: The Treasury bought silver using funds from the ESF (Leaven, 1939:266), established under the Gold Reserve Act of Jan.' 34 , the paper proceeds of which had been created out of nothing by re-valuing the dollar from $\$ 20.67$ to $\$ 35 / \mathrm{oz}$. Then, on 9th Aug.1934 Roosevelt issued a proclamation (supplementary to the Dec.'33 proclamation) and an executive order, provided for the "nationalization" of all domestic stocks of silver requiring all silver in the U.S. to be delivered to U.S. mints at a price of $\$ 1.2929 / \mathrm{oz}$ less $61.32 \%$ ( $\$ 0.7928)$ seigniorage or a mint equivalent price of 50.01 cents, equivalent to 49.96 cents at .999 fine (slightly above market) - this measure was similar to the "nationalization" of gold, with the intention of capturing profits from the rising price of silver: one important difference was that silver coins were excluded from the recall, since a silver dollar was worth less in the market than its face value of $\$ 1.2929 / \mathrm{oz}$. The silver policy did not succeed in increasing the market price level to its monetary value of $\$ 1.2929 / \mathrm{oz}$, nor reach a $1: 3$ ratio of the monetary stocks of silver to gold, but between $1934-19381.7 \mathrm{Bn}$ ozs were acquired at a book value of $\$ 0.5689 / \mathrm{oz}$ or $\$ 0.97 \mathrm{Bn}$ and a monetary value of $\$ 2.2 \mathrm{Bn}$ at $\$ 1.2929 / \mathrm{oz}$. The Treasury issued silver certificates equal to the book value and treated the seigniorage as a 
budget receipt, adding about $\$ 1 \mathrm{Bn}$ to the stock of money; another $1.5 \mathrm{Bn}$ ozs added another $\$ 1 \mathrm{Bn}$ to money supply by mid 1961. President Kennedy requested Congress to repeal the legislation in Jan.1962, which was passed in June 1963 (Leavens, 1939) (Friedman, 1963).

Note 22. LBMA silver price data is from London Silver Market Fixing Ltd quoted in dollars.

Note 23. LBMA quotes average daily and monthly "fix" prices in GBP and USD for both gold and silver from 1968. The Silver Institute quotes prices from 1975-present and Kitco from 1792-present, both in USD.

Note 24. Houghton silver prices from 1693-1697 (Li, 1963). Castaing's original folios available from the Guildhall Library (see Caisting) and Jastram (1981) to 4 decimal places.

Note 25. Jastram (1981).

Note 26. Jastram (1981).

Note 27. Jastram (1981); Shrigley (1935, table at end of book) quotes market gold:silver ratios from 1687-1932, actual gold prices from 1870-1932, actual silver prices from 1833-1933; source for both Jastram \& Shrigley is Sharps, Pixley (Pixley \& Abell).

Note 28. LBMA silver price data is from London Silver Market Fixing Ltd quoted in dollars.

Note 29. The Warren and Pearson Index (Warren, 1933) of wholesale commodity prices is effectively from 1749-1932, and incorporates the Department of Labor's Wholesale Prices Index, which was first published (on a monthly basis) in 1902 for the period 1890-1901. In the early years it included 250-260 commodities, but from 1926 it included 784 commodities and in 1932 it was published on a weekly basis.

Note 30. The Bureau of Labor's wholesale Producer Price Index-Commodities (PPI) is adopted from 1979 to 2009. Jastram (1981) also provides The Bureau of Labor's Wholesale Prices Index (WPI) from 1933 to 1979. The WPI and PPI are calculated according to a modified Laspèyres formula, which estimates the price of a fixed basket of goods and services.

Note 31. Sources identified for price data are summarized in the figures as; for PG-[WP] Warren \& Pearson (1935), [UST] U.S. Treasury (Friedman, 1963), [HCL] Houghton, Castaign's, Lloyds List (Li, 1963) (UK Data Archive) (Neal, 1996) (Jastram, 2009), [PP] Parliamentary Papers (Jastram, 2009), [L] Lutyens (Jastram, 2009), [SP] Sharps, Pixley Ltd (Jastram, 2009, Shrigley, 1935), [LBMA] LBMA: London Gold Market Fixing Ltd; for PS-[UST] U.S. Treasury (Warren, 1935), [HCL] (Li, 1963) (UK Data Archive) (Neal, 1996) (Jastram, 1981), [PP] (Jastram, 1981), [L] (Jastram, 1981), [SP] Sharps, Pixley Ltd (Jastram 1981, Shrigley, 1935), [USGS] Bureau of Mines, USGS (Warren, 1935) (Friedman, 1963), [LBMA] LBMA: London Silver Market Fixing Ltd; for exchange rates - [W, O] (Warren, 1935) (Officer, 2007, 2013-b); for commodity prices-[WP] Warren \& Pearson (Warren, 1933), [BLS] Bureau of Labor Statistics (Jastram, 1981) (BLS, PPI-Commodities).

Note 32. Exchange rate sources 1792-1829 actual data from White (Fenton, 1879), thereafter Officer (2007).

Note 33. By securing the services of Senator John Sherman of Ohio, Chairman of the Senate Finance Committee whom introduced the Act of 1973, and had traveled to London in the Spring of 1867, on his way to the international monetary conference in Paris that same year (Clark, 1894). By 1894, global redemption money according to the U.S. Mint was $\$ 3.7$ billion in gold and $\$ 3.8$ billion in silver or a total of $\$ 7.5$ billion. The Chicago Daily News estimated Rothschilds owned $\$ 1.6$ billion of gold, and with the de-monetization of silver, redemption money was reduced by half, thereby doubling their wealth and increasing their control (Harvey, 1894).

Note 34. The price of silver acquired under the Silver-Purchase Proclamation of Dec. 1933 was $\$ 1.2929 / \mathrm{oz}$ less $50 \%$ seigniorage or a mint equivalent price of 64.65 cents (about a $24 \%$ premium to the market price of 49 cents, thereby ensuring all production would be purchased by the Treasury), and the price under the Silver Purchase Act of May 1934 was $\$ 1.2929 / \mathrm{oz}$ less $61.32 \%$ (\$0.7928) seigniorage or a mint equivalent price of 50.01 cents, equivalent to 49.96 cents at .999 fine (slightly above market). Between 1934-1938 1.7Bn ozs were acquired at a book value of $\$ 0.5689 / \mathrm{oz}$ or $\$ 0.97 \mathrm{Bn}$ and a monetary value of $\$ 2.2 \mathrm{Bn}$ at $\$ 1.2929 / \mathrm{oz}$. The Treasury issued silver certificates equal to the book value and treated the seigniorage as a budget receipt, adding about $\$ 1 \mathrm{Bn}$ to the stock of money; another $1.5 \mathrm{Bn}$ ozs added another $\$ 1 \mathrm{Bn}$ to money supply by mid 1961 . President Kennedy requested Congress to repeal the legislation in Jan.1962, which passed in June 1963: he was assassinated in Nov.'63 (Leavens, 1939) (Friedman, 1963).

Note 35. The gold stock increased from 193.3Mn Ozs x $\$ 20.67 / \mathrm{oz}=\$ 3,995.5 \mathrm{Mn}$ in Mar.1933 to 195.1Mn Ozs x $\$ 35 / \mathrm{oz}=\$ 6,828.5 \mathrm{Mn}$ in Jan.1934, or a profit of $\$ 2,833 \mathrm{Mn}$. By issuing gold certificates in lieu of its gold stock the Treasury turned over the certificates to the Federal Reserve in exchange for a deposit credit convertible into 
FRNs or payable by cheque. Gold stock excludes gold coin in circulation which between Mar.'33 and Jan.'34 dropped from 17.9 to $13.9 \mathrm{Mn}$ Ozs or \$287Mn@ @ \$20.67/oz and mostly retained illegally by the public (Friedman, 1963)

Note 36. Lbs/FTO = (troy grains per oz/[fine grains per USD x USD price of wheat per bushel]) $\mathrm{x}$ lbs per bushel. The $1929 \mathrm{lbs} / \mathrm{FTO}$ for wheat $=1,017=(480 /[23.22 \times 1.22]) \times 60$; for corn $=1,258=(480 /[23.22 \times 0.92]) \times 56$.

Note 37. Nominal PG on 21 January 1980 x (CPI December 2009/CPI January 1980) = Real PG at December 2009, or the inflation adjusted PG. USD850 x (215.949/77.8) = USD2,359.34, or about USD2,360.

Note 38. A.H. Gibson noticed the close relationship, under the 19th century English gold standard, between the rate of interest, as measured by the yield on Consols, and the level of prices, as measured by an index of wholesale prices (Gibson, 1923). Keynes referred to the problem as a paradox (Keynes, 1930) for it seemed to contradict the prediction of classical monetary theory that the interest rate is independent of the price level, being the price of loanable funds, whilst the price level is determined by the money supply as described by the quantity of money theory of prices. Abdullah (April, 2013) provided a satisfactory explanation of the Gibson Paradox operating under both the gold standard and the fiat standard with a monetary theory of value, and observed that there is clear co-movement between real interest rates and real prices (nominal prices expressed in terms of gold), the latter being the inverse of real gold (PPG). Hence, an inverse relationship exists between real interest rates and real gold.

\section{Copyrights}

Copyright for this article is retained by the author(s), with first publication rights granted to the journal.

This is an open-access article distributed under the terms and conditions of the Creative Commons Attribution license (http://creativecommons.org/licenses/by/3.0/). 